\title{
Gamma Knife Radiosurgery For Brain Vascular Malformations: Current Evidence And Future Tasks
}

This article was published in the following Dove Press journal:

Therapeutics and Clinical Risk Management

\author{
Hirotaka Hasegawa' \\ Masaaki Yamamoto (D) ${ }^{2}$ \\ Masahiro Shin' \\ Bierta E Barfod ${ }^{2}$ \\ 'Department of Neurosurgery, The \\ University of Tokyo Hospital, Tokyo, \\ Japan; ${ }^{2}$ Katsuta Hospital Mito Gamma \\ House, Hitachinaka, Ibaraki, Japan
}

\begin{abstract}
Gamma Knife radiosurgery (GKRS) has long been used for treating brain vascular malformations, including arteriovenous malformations (AVMs), dural arteriovenous fistulas (DAVFs), and cavernous malformations (CMs). Herein, current evidence and controversies regarding the role of stereotactic radiosurgery for vascular malformations are described. 1) It has already been established that GKRS achieves $70-85 \%$ obliteration rates after a 3-5-year latency period for small to medium-sized AVMs. However, late radiation-induced adverse events (RAEs) including cyst formation, encapsulated hematoma, and tumorigenesis have recently been recognized, and the associated risks, clinical courses, and outcomes are under investigation. SRS-based therapeutic strategies for relatively large AVMs, including staged GKRS and a combination of GKRS and embolization, continue to be developed, though their advantages and disadvantages warrant further investigation. The role of GKRS in managing unruptured AVMs remains controversial since a prospective trial showed no benefit of treatment, necessitating further consideration of this issue. 2) Regarding DAVFs, GKRS achieves $41-90 \%$ obliteration rates at the second post-GKRS year with a hemorrhage rate below 5\%. Debate continues as to whether GKRS might serve as a first-line solo therapeutic modality given its latency period. Although the post-GKRS outcomes are thought to differ among lesion locations, further outcome analyses regarding DAVF locations are required. 3) GKRS is generally accepted as an alternative for small or medium-sized $\mathrm{CMs}$ in which surgery is considered to be too risky. The reported hemorrhage rates ranged from $0.5-5 \%$ after GKRS. Higher dose treatments ( $>15$ Gy) were performed during the learning curve, while, with the current standard treatment, a dose range of 12-15 Gy is generally selected, and has resulted in acceptable complication rates $(<5 \%)$. Nevertheless, further elucidation of long-term outcomes is essential.
\end{abstract}

Keywords: arteriovenous malformation, cavernous malformation, dural arteriovenous fistula, gamma knife radiosurgery, stereotactic radiosurgery

\section{Introduction}

Based on the concept of stereotactic radiosurgery that was first introduced in 1951, the gamma unit was designed by Lars Leksell using multiple ${ }^{60} \mathrm{Co}$ sources focused at a fixed center. ${ }^{1,2}$ Characterized by its single-session focused irradiation with high accuracy and sharp dose fall-off, ${ }^{3,4}$ gamma knife radiosurgery (GKRS) was first introduced clinically in 1968 and has since been used to treat more than one million patients worldwide with a variety of cerebral/cranial conditions. ${ }^{2,5-7}$ Arteriovenous malformation (AVM), dural arteriovenous fistula (DAVF), and cavernous malformation (CM) are the main GKRS targets; all are categorized as brain vascular malformations and are essentially caused by arteriovenous shunting, though their
Correspondence: Masaaki Yamamoto Katsuta Hospital Mito GammaHouse, 5I25-2 Nakane, Hitachi-Naka, Ibarak 3I2-00II, Japan

Tel $+8|-29-27|-00 \mid I$

Fax +8I-29-274-1475

Email BCD06275@nifty.com

Therapeutics and Clinical Risk Management 2019:15 I35I-1367 
conditions and responses to GKRS are entirely different. Numerous studies, including systematic reviews and multicenter retrospective analyses, have examined radiosurgical outcomes of these disorders and the efficacy of GKRS has been well established. Nevertheless, several problems remain that must be addressed. Herein, we summarize current evidence supporting the use of GKRS for such brain vascular malformations and discuss persisting controversies.

\section{GKRS Procedures For Vascular Malformations}

Using local anesthesia with or without sedation, the patient's head is fixed in a Leksell Coordinate Frame G (Elekta AB, Stockholm, Sweden). The patient is then sent to a radiographic suite to undergo stereotactic imaging studies, including magnetic resonance imaging (MRI), computed tomography (CT), and digital subtraction angiography (DSA). These imaging studies are performed with fitting of an appropriate indicator on the frame, which imposes fiducials on images of the patient. The acquired image dataset is then sent to GammaPlan (Elekta AB), a radiosurgical planning software program. In creating the radiosurgical plan, an appropriate prescription dose is aimed at the target's margin usually using a 50-60\% isodose gradient while a 70-90\% isodose gradient occasionally is used in patients with a relatively small target. A margin, the setting of which is usually recommended in linac-based radiosurgery, is not required.

\section{GKRS For Arteriovenous Malformation}

\section{Current Evidence}

Brain AVM is the most common brain vascular malformation with a prevalence of just under 10 per $100,000 .^{8-10}$ The hemorrhage risk is reported to be approximately $3 \%$ /year. Once a hemorrhage occurs, the possibilities of neurologic deficits and death are $<50 \%$ and $<10 \%$, respectively. ${ }^{8,11,12}$ Therefore, the treatment goal is to eliminate the risk of hemorrhage, which can be achieved by isolating the nidus from the circulation. GKRS is considered to be a main therapeutic modality and is often applied to small to medium-sized AVMs. ${ }^{8,13-15}$

Generally, nidus obliteration can be achieved in $70-85 \%$ of patients after a 3-5 year latency period. ${ }^{15-22}$ Though DSA is still the gold standard method for confirming nidus obliteration, there is a recent tendency to avoid
DSA due to its invasiveness. MRI is generally regarded as an acceptable alternative, exhibiting 77-85\% sensitivity and $89-95 \%$ specificity. $^{23,24}$ Radiosurgical dose and AVM size are the factors most strongly influencing nidus obliteration. $^{15-18,20,21,25-45}$ The Pittsburgh radiosurgical AVM score ${ }^{17}$ with its modification ${ }^{41}$ and the Virginia radiosurgical AVM scale ${ }^{25}$ are two major scoring systems which aid neurosurgeons in predicting post-radiosurgical outcomes. As to disadvantages of GKRS, approximately $30 \%$ of patients suffer from perinidal $\mathrm{T} 2$-signal intensity change within 2 years after the procedure, but this becomes symptomatic in less than $10 \%$ and permanent in only 3\%. ${ }^{15,46-51}$ Post-GKRS hemorrhage is rare, ${ }^{52-55}$ and the risk does not increase, remaining the same or decreasing during the latency period. ${ }^{52}$ Whether nidus obliteration means "complete" eradication of hemorrhage risk remains debatable. ${ }^{56}$ Bleeding due to recanalization of a onceobliterated nidus, albeit quite rare, has been reported. ${ }^{57,58}$

\section{Late Radiation-Induced Adverse Events (RAEs)}

Since the late 1990s, an increasing number of studies have described late RAEs, including cyst formation ( $\mathrm{CF}$ ), chronic encapsulated hematoma (CEH), and tumorigenesis. ${ }^{59}$ Radiation-induced chronic inflammation appears to play an important role in the former two conditions, ${ }^{60,61}$ suggesting that target size is strongly associated with their occurrence. $^{62-64}$ The other risk factors include lobar location, higher prescription dose, and history of embolization as pre-GKRS factors, the occurrence of early edema, additional irradiation, and the state of nidus obliteration as postGKRS factors. ${ }^{63-71} \mathrm{CF} / \mathrm{CEH}$ develops approximately $6.5-$ 11.8 years after irradiation, and the cumulative incidences are estimated to range from $2.8-7.7 \%$ at 10 years and $7.6-$ $12.5 \%$ at 15 years. $^{64-, 66,68}$ Though the optimal treatment remains a source of controversy, surgical resection is widely regarded as a standard option. However, fluid diversion, including cyst-peritoneal shunt and ommaya reservoir placement, are minimally invasive alternatives for exclusively cystic lesions. ${ }^{64-66,68}$ Oral corticosteroids may help reduce the associated edema and alleviate symptoms; however, the long-term effects remain unknown. ${ }^{64,68}$ Previous studies on $\mathrm{CF} / \mathrm{CEH}$ are summarized in Table 1. ${ }^{62-64,66-68,72-74}$

Regarding radiation-induced tumorigenesis, the majority of such lesions are malignant glioma. ${ }^{64,75-79}$ Attempts have been made to calculate the radiation-induced tumorigenesis incidence, which has been roughly estimated to be 
Table I Literature Review On Late RAEs (Studies With $\geq 100$ patients)

\begin{tabular}{|c|c|c|c|c|c|c|c|}
\hline Author & Year & $\mathbf{N}$ & $\begin{array}{l}\text { Median } \\
\text { Observation } \\
\text { Period }(y)\end{array}$ & $\begin{array}{l}\text { Definition } \\
\text { Of Late } \\
\text { RAEs }\end{array}$ & $\begin{array}{l}\text { Incidence (Crude } \\
\text { Or Cumulative } \\
\text { Rate) }\end{array}$ & Risk Factors & $\begin{array}{l}\text { Remarks/ } \\
\text { Treatment } \\
\text { Modality }\end{array}$ \\
\hline T. Hasegawa ${ }^{72}$ & 2019 & 189 & $11.3^{*}$ & CF, CEH, RIT & $\begin{array}{l}7.2 \% / 15 \text { y } \\
\text { (cumulative) }\end{array}$ & Larger nidus volume & $\begin{array}{l}\text { All pediatric } \\
\text { patients. }\end{array}$ \\
\hline H. Hasegawa ${ }^{64}$ & 2018 & 581 & $11.8^{*}$ & CF, CEH & $\begin{array}{l}7.6 \% / 15 \text { y } \\
\text { (cumulative) }\end{array}$ & $\begin{array}{l}\text { Diameter }>22 \mathrm{~mm} \text {, lobar location, } \\
\left(\text { Early edema, secondary SRS) }{ }^{\dagger}\right.\end{array}$ & GKRS \\
\hline Pomeraniec $^{66}$ & 2018 & 1159 & $\begin{array}{l}5.9(\mathrm{w} C F) / 11.0 \\
\text { (wo CF) }\end{array}$ & $\mathrm{CF}$ & $1.5 \%$ (crude) & $\begin{array}{l}\text { Larger number of isocenters, } \\
\text { early edema, longer follow-up }\end{array}$ & GKRS \\
\hline Pollock ${ }^{68}$ & 2017 & 233 & 9.8 & ND & $\begin{array}{l}12.5 \% / 15 \text { y } \\
\text { (cumulative) }\end{array}$ & $\begin{array}{l}\text { Early edema, nidus occlusion, SRS } \\
\text { before April } 1997\end{array}$ & GKRS \\
\hline Nakajima $^{73}$ & 2016 & 404 & 4.9 & CF, CEH & $5.0 \%$ (crude) & No factor & GKRS \\
\hline Matsuo ${ }^{67}$ & 2014 & 109 & ND & $\mathrm{CF}$ & $5.5 \%$ (crude) & NA & $\begin{array}{l}\text { Linac- } \\
\text { radiosurgery }\end{array}$ \\
\hline Parkhutik $^{62}$ & 2013 & 102 & 5.3 & Radionecrosis & $6.9 \%$ (crude) & Diameter $>3 \mathrm{~cm}$, secondary SRS & GKRS \\
\hline $\operatorname{Pan}^{74}$ & 2005 & 1203 & See below ${ }^{\dagger}$ & $\mathrm{CF}$ & $3.6 \%$ (crude) & $\begin{array}{l}\text { Addition of embolization, early } \\
\text { edema }\end{array}$ & GKRS \\
\hline $\operatorname{lzawa}^{63}$ & 2005 & 237 & $6.8^{*}$ & $\mathrm{CF}$ & $3.4 \%$ (crude) & $\begin{array}{l}\text { Higher central dose, larger nidus } \\
\text { volume, nidus occlusion, lobar } \\
\text { location }\end{array}$ & GKRS \\
\hline
\end{tabular}

Notes: *Mean. ${ }^{\dagger}$ Observation period < 5 y, 674 patients; 5-10 y, 332 patients; II-15 y, 167 patients; 16-23 y, 30 patients.

Abbreviations: AVM, arteriovenous malformation; CF, cyst formation; CEH, chronic encapsulated hematoma; GKRS, gamma knife radiosurgery; NA, not assessed; ND, not described; RAE, radiation adverse event; RIT, radiation-induced tumor; y, year(S); w, with; wo, without.

less than $0.2 \% .{ }^{64,75,76}$ The actual incidence, however, has yet to be determined due to the rarity of this condition.

\section{Staged GKRS For Large AVMs}

Large AVMs are challenging targets. Radiosurgical doses are generally reduced for fear of RAEs, which in turn could decrease the obliteration rate and might eventually result in a higher hemorrhage rate. ${ }^{80}$ In short, it is important to balance the therapeutic effect and risks. Accumulated evidence tells us that stand-alone GKRS for AVMs $>10 \mathrm{~mL}$ is controversial and that staged GKRS is an alternative that is frequently considered. ${ }^{49}$

There are two distinct staging methods: volume-staged GKRS (VSGKRS) and dose-staged GKRS. In VSGKRS, the entire nidus volume is divided into 2 or 3 parts, which are then irradiated independently with intervals of several months (usually 3 to 6 months). ${ }^{81-91}$ On the other hand, in dose-staged GKRS, the entire nidus is irradiated repeatedly with an attenuated dose until a planned cumulative dose has been fully delivered. ${ }^{91-94}$ Although no definitive conclusion has yet been reached, retrospective evidence indicates the superiority of VSGKRS. ${ }^{95,96}$

Previous studies on VSGKRS are summarized in Table 2. ${ }^{89,94,97,98-103}$ The crude obliteration rates after VSGKRS range between $33 \%$ and $72 \%$, the exception being one study reporting $13 \%$; this broad range may be due to marked differences in nidus volumes among studies (mean, 16.8-60 mL) and the wide variety of prescription doses administered (mean, 15.5-20.8 Gy). ${ }^{81-91,101}$ It seems that a dose of at least 17 Gy for each session is needed to obtain a favorable obliteration rate; if lesions are treated with $\geq 17 \mathrm{~Gy}$, the obliteration rate approaches $60 \%{ }^{97,102}$ The other factors that potentially contribute to successful obliteration include larger than $20 \mathrm{~Gy}$-volume coverage ${ }^{97}$ and a single drainer vessel. ${ }^{89}$ However, these results are not consistent and further research is needed. Regarding the disadvantages of VSGKRS, relatively high hemorrhage rates are the primary concern, with crude rates ranging from $4.5 \%$ up to $33 \% .^{81-91,101}$ The occurrence of RAEs would presumably be greatly affected by the dose, volume, location, and follow-up duration, and is thus 


\begin{tabular}{|c|c|c|c|c|c|c|c|c|c|c|}
\hline 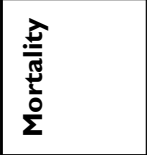 & ○े & 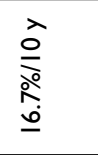 & $\begin{array}{l}\underset{\hat{v}}{\stackrel{0}{0}} \\
\text { }\end{array}$ & 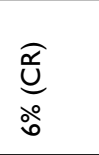 & 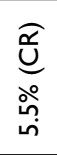 & 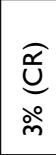 & 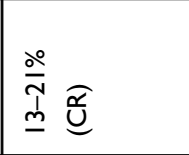 & 乏 & 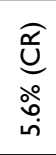 & 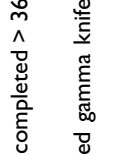 \\
\hline 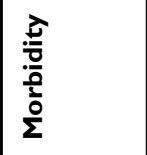 & 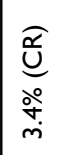 & 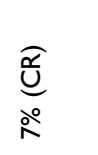 & 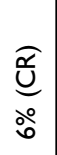 & 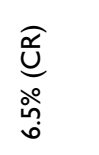 & 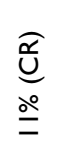 & 之 & 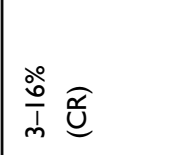 & $\begin{array}{l}\underset{\widetilde{\tilde{U}}}{\stackrel{0}{\circ}} \\
\text { in }\end{array}$ & 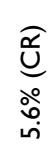 & 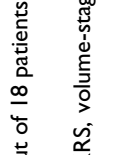 \\
\hline 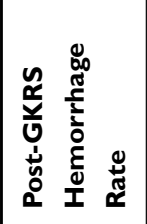 & ৯े & 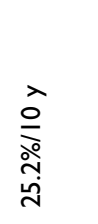 & 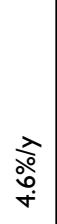 & 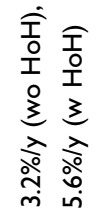 & $\begin{array}{l}\stackrel{\lambda}{\circ} \\
\text { مे } \\
\dot{m}\end{array}$ & $\begin{array}{l}\widehat{\widetilde{f}} \\
\stackrel{0}{\Xi} \\
=\end{array}$ & 希 & 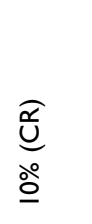 & $\frac{\lambda}{\frac{\lambda}{0}}$ & 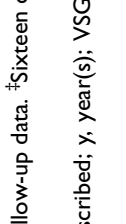 \\
\hline 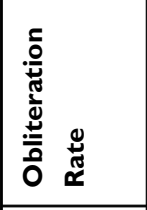 & 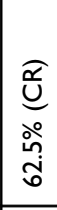 & 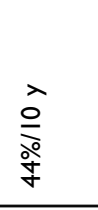 & 方 & $\begin{array}{c}\frac{\lambda}{\frac{1}{0}} \\
\frac{\partial}{0} \\
\end{array}$ & & 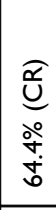 & 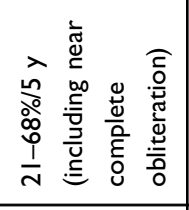 & 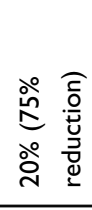 & $\frac{\hat{0}}{\stackrel{0}{\circ}}$ & 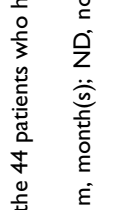 \\
\hline 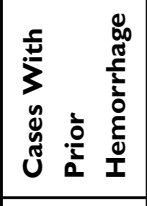 & $\begin{array}{l}\stackrel{\circ}{\rho} \\
\stackrel{\infty}{\infty} \\
\stackrel{n}{n}\end{array}$ & $\stackrel{\circ}{\stackrel{\gamma}{\sim}}$ & 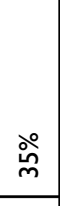 & ஓ̊ & ڤ̊ํㅇ & సે & $\begin{array}{l}\stackrel{\circ}{\circ} \\
\text { 命 }\end{array}$ & ○ें & $\begin{array}{l}\stackrel{\circ}{\circ} \\
\text { ڤં }\end{array}$ & 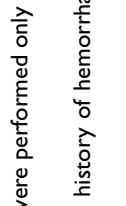 \\
\hline 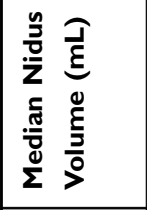 & 亘 & 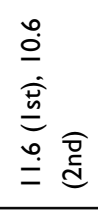 & $\underset{\mathfrak{N}}{ }$ & $\hat{\alpha}$ & $\stackrel{\infty}{\infty}$ & 菅 & $\begin{array}{l}m \\
\stackrel{m}{\hat{T}} \\
\alpha \\
\underline{\infty} \\
\underline{\infty}\end{array}$ & 로 & ત્તે & 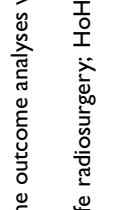 \\
\hline 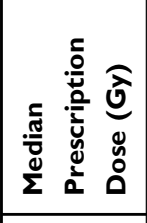 & $\stackrel{*}{\underline{\omega}}$ & $\underline{\circ}$ & $\underline{\bullet}$ & $\stackrel{\stackrel{n}{\Lambda}}{=}$ & 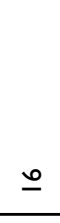 & $\overline{\overline{1}}$ & 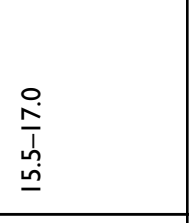 & ㅇ & $\underline{\underline{n}}$ & 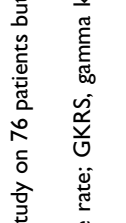 \\
\hline 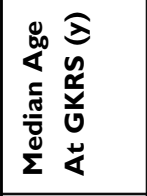 & $\stackrel{*}{\sim}$ & ᄋ & $\bar{m}$ & $\hat{m}$ & $\stackrel{m}{m}$ & 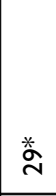 & $\dot{m}$ & $\stackrel{\infty}{m}$ & $\stackrel{\sim}{m}$ & 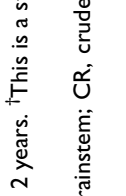 \\
\hline 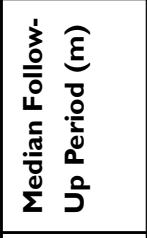 & $\stackrel{*}{\%}$ & २ & $\stackrel{+}{\infty}$ & $\stackrel{\infty}{\stackrel{\infty}{\Lambda}}$ & ñ & $\begin{array}{l}\text { * } \\
\text { dे } \\
\text { on }\end{array}$ & $\begin{array}{l}\stackrel{0}{\tilde{O}} \\
\frac{0}{1} \\
\stackrel{0}{n}\end{array}$ & $\stackrel{*}{\stackrel{*}{q}}$ & $\begin{array}{c}+\stackrel{+}{0} \\
\wedge\end{array}$ & 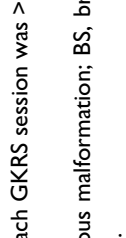 \\
\hline $\mathbf{z}$ & సి & ㅇ & $\dot{m}$ & $\underset{+}{+}$ & $\underline{\infty}$ & $\stackrel{\leftrightarrow}{q}$ & a & 유 & $\underline{\infty}$ & 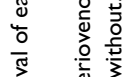 \\
\hline 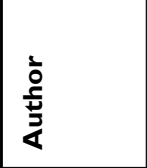 & 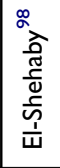 & 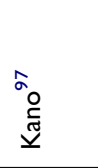 & $\begin{array}{l}\frac{\overline{0}}{\overline{\mathrm{u}}} \\
\frac{\mathrm{O}}{\overline{0}} \\
\mathrm{o}\end{array}$ & 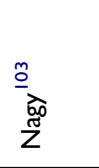 & 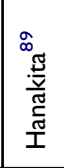 & 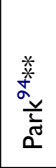 & 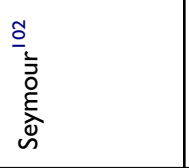 & 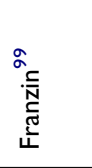 & $\begin{array}{l}\frac{8}{00} \\
\stackrel{0}{5} \\
\stackrel{\frac{5}{I}}{I}\end{array}$ & 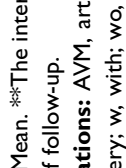 \\
\hline ঠ্ & $\frac{a}{2}$ & $\stackrel{\infty}{i}$ & $\overline{\bar{N}}$ & $\overline{\bar{N}}$ & $\frac{\circ}{2}$ & $\frac{0}{2}$ & $\frac{0}{2}$ & $\frac{0}{2}$ & $\frac{\text { i }}{2}$ & 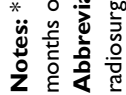 \\
\hline
\end{tabular}


difficult to predict; however, the rate is somewhere between $0 \%$ and $40 \%{ }^{81-90,91,101}$ A recent systematic review by Ilyas et al noted that the rates of obliteration, symptomatic RAEs, post-radiosurgical hemorrhage, and mortality were $41.2 \%, 13.7 \%, 19.5 \%$, and $7.4 \%$, respectively. ${ }^{95}$ Thus, VSGKRS is a therapeutic modality still undergoing development. Given the scarcity of cases in individual centers, a multi-center study is needed for further evaluation.

\section{Combination Of GKRS And Embolization For Large AVMs}

The other option for large AVMs is a combination of neoadjuvant nidus embolization and definitive GKRS. Previous relatively large studies reporting this combination are summarized in Table 3. ${ }^{104-113}$ According to several recent studies, the crude obliteration rates range from $24-72 \%$, and 5-year obliteration rates from $31-60 \% .^{24,104-118} \mathrm{~A}$ recent systematic review found the obliteration rate to be $41.0 \%$, the 3 -year hemorrhage rate to be $7.3 \%$, and the RAE rate to be $3.3 \%{ }^{119}$ however, these results might be misleading due to volume discrepancies and how they are defined. First, median/mean volumes in the studies included in this systematic review varied significantly; the smallest was $2.8 \mathrm{~mL}$ and the largest $29.5 \mathrm{~mL}$. Second, most of the prior studies used residual AVM volume after embolization as a baseline value, ${ }^{104,105,108,109,115,120-122}$ while others employed the pre-embolization volume, ${ }^{107,110-114}$ and two studies did not describe volume in detail. ${ }^{116,117}$ Since AVM volume significantly affects radiosurgical outcomes, these discrepancies present a major obstacle to interpreting the results.

This combination was initially deemed to be ideal because embolization can reduce the nidus volume, with minimal invasiveness, down to the level at which GKRS could be suitably applied. ${ }^{123,124}$ However, several studies later suggested that this approach might be associated with a reduction in the obliteration rate. ${ }^{16,109,114,119,120}$ This reduction might be attributable to several factors including recanalization of the embolized AVM compartments, increased difficulty in AVM demarcation for radiosurgical planning, and increased angiogenesis after embolization. ${ }^{36,37,123,125,126-128}$ Nevertheless, it would be premature to abandon this combination strategy, given the volume issues discussed above. What we can learn from the relevant studies is that the obliteration rate for post-embolized AVMs might be lower than that for nonembolized AVMs with volumes similar to the residual volumes of embolized AVMs. Comparing post-embolized AVMs to non-embolized AVMs with volumes similar to the pre-embolized volume of the former would yield different results. Further studies must be designed to ascertain whether the combination therapy is beneficial for larger AVMs, by comparing the overall outcomes of both embolization and GKRS to a GKRS-based strategy without embolization, with adjustment for the pre-intervention volume between the two cohorts.

\section{GKRS For Unruptured AVMs}

Therapeutic interventions for unruptured AVMs were not regarded as being controversial until the Randomized trial of Unruptured Brain Arteriovenous malformations (ARUBA study) failed to show any advantages to treatment. $^{129}$ Since then, however, a significant number of concerns about and criticisms of the ARUBA study have been raised. ${ }^{130}$ From the standpoint of GKRS, the short follow-up duration would the factor most significantly impairing the reliability of the results; a median follow-up of $<3$ years is inadequate to see the benefits of GKRS that would not usually preclude the possibility of AVM rupture until obliteration is achieved after a 3-5 year latency period. Another significant issue is the lack of details regarding the treatment arms; the actual outcomes after GKRS were not documented in detail. To date, several gamma knife centers have reported comparison studies between "ARUBA-eligible patients" and the medically-managed patients in the ARUBA study, and obtained more favorable outcomes in GKRS cohorts in the late phase (Table 4). ${ }^{131-136}$ Therefore, GKRS appears to be warranted for small- to medium-sized unruptured AVMs. Nevertheless, the ARUBA study was undoubtedly a turning point in the management of unruptured AVMs in the sense that it underscored the importance of being fully aware of the invasiveness of treatment and its complications when treating asymptomatic AVMs.GKRS for dural arteriovenous fistula

\section{Current Evidence}

DAVFs, accounting for $10-15 \%$ of intracranial arteriovenous shunt disorders, are acquired arteriovenous shunts involving the dura mater, where arterialized dural sinuses become an obstacle to normal cerebral venous return, eventually resulting in intracranial hemorrhage and/or nonhemorrhagic neurological deficits due to venous hyperremia. ${ }^{137-142}$ Presence of cortical venous drainage (CVD) and prior hemorrhage are well-known risk factors 


\begin{tabular}{|c|c|c|c|c|c|c|c|c|c|}
\hline 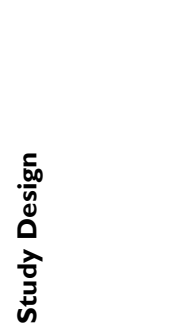 & 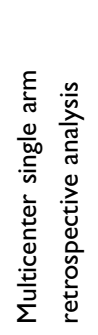 & 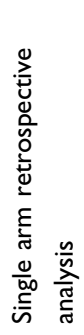 & 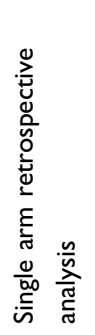 & 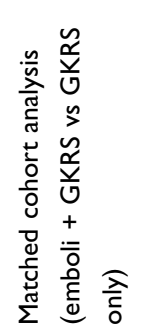 & 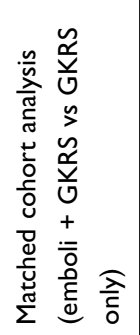 & 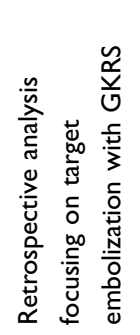 & 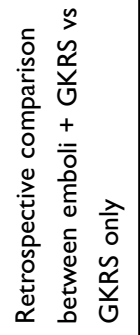 & 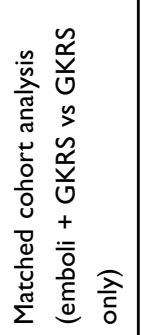 & 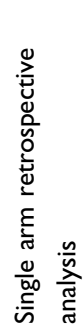 \\
\hline 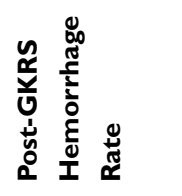 & $\begin{array}{l}\stackrel{\circ}{\doteqdot} \\
\dot{\check{U}}\end{array}$ & 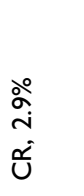 & $\frac{\lambda}{\stackrel{\lambda}{\circ}}$ & $\begin{array}{l}\text { ㅇํㅇ } \\
\text { ì }\end{array}$ & $\begin{array}{l}\stackrel{\circ}{\dot{0}} \\
\stackrel{\sim}{U}\end{array}$ & 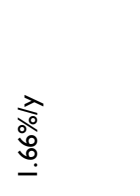 & $\begin{array}{l}\stackrel{\circ}{0} \\
0 \\
\dot{0} \\
\tilde{U}\end{array}$ & $\begin{array}{l}\stackrel{\lambda}{\stackrel{े}{\circ}} \\
\stackrel{i}{i}\end{array}$ & 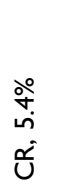 \\
\hline 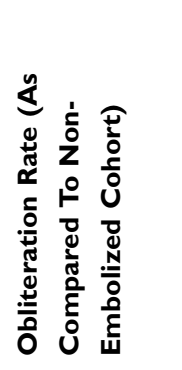 & $\begin{array}{l}\stackrel{\circ}{9} \\
\text { ठ̊ } \\
\text { Ũ }\end{array}$ & 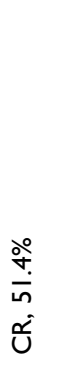 & 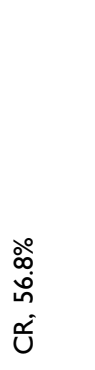 & 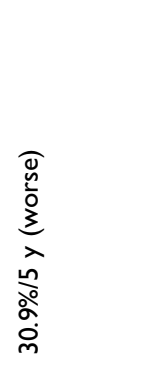 & 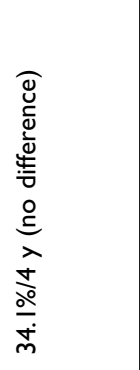 & $\begin{array}{l}\stackrel{\text { ஸे }}{\infty} \\
\stackrel{0}{0} \\
\text { Ũ }\end{array}$ & 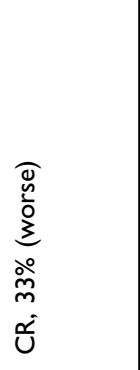 & 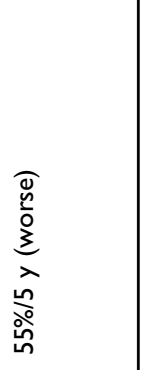 & 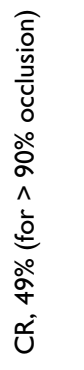 \\
\hline 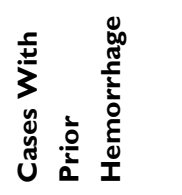 & ڤ̊ํํ & ১̊ำ & $\frac{\stackrel{\circ}{\infty}}{\stackrel{\infty}{+}}$ & ○ें & ○े & 今ें & $\begin{array}{l}\stackrel{\circ}{\infty} \\
\underset{f}{\text { d }}\end{array}$ & $\stackrel{\text { ळे }}{\text { }_{n}^{\circ}}$ & $\begin{array}{l}\stackrel{\circ}{\text { ڤे }} \\
\text { ᄋे }\end{array}$ \\
\hline 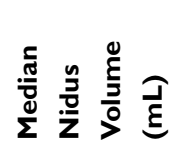 & $\begin{array}{l}\stackrel{*}{*} \\
\stackrel{\infty}{\underline{m}} \\
\dot{g} \\
\dot{0}\end{array}$ & 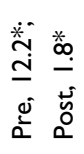 & 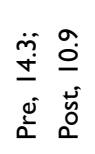 & $\begin{array}{l}\stackrel{0}{+} \\
\dot{+} \\
\dot{\Delta} \\
0\end{array}$ & 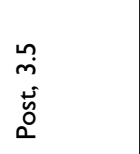 & 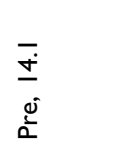 & \begin{tabular}{l}
$*$ \\
\multirow{2}{*}{} \\
$\dot{+}$ \\
$\dot{\Delta}$ \\
0
\end{tabular} & 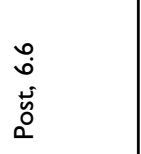 & 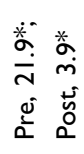 \\
\hline 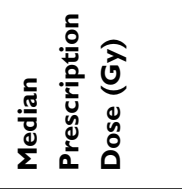 & 之 & ㅇ & 吕 & 이 & $\approx$ & $\underline{m}$ & $\begin{array}{l}\text { 菓 } \\
\text { o- }\end{array}$ & $\underline{\infty}$ & २ \\
\hline 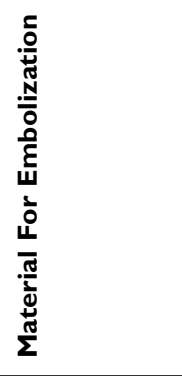 & 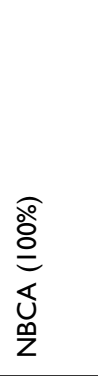 & 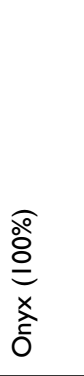 & 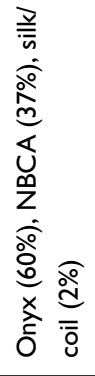 & 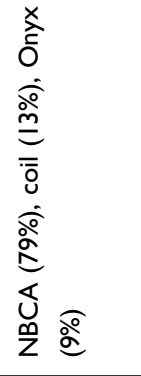 & 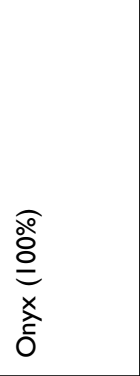 & 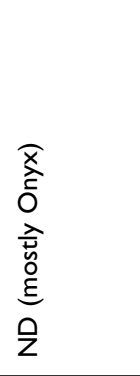 & 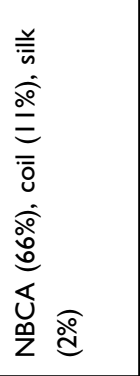 & 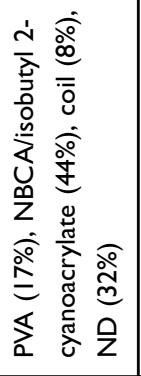 & 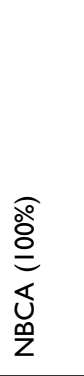 \\
\hline$z$ & $\stackrel{m}{\kappa}$ & $\stackrel{\stackrel{m}{m}}{ }$ & $\underline{\widetilde{\sigma}}$ & $\stackrel{\mathcal{I}}{d}$ & $\stackrel{\mathscr{\sim}}{\sim}$ & $\begin{array}{l}\text { 芧 } \\
\text { f }\end{array}$ & $\frac{n}{N}$ & ¿ి & $\hat{m}$ \\
\hline 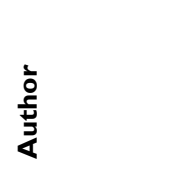 & 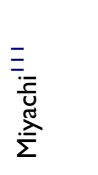 & 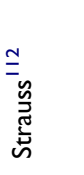 & $\begin{array}{l}\stackrel{m}{=} \\
\stackrel{0}{I}\end{array}$ & 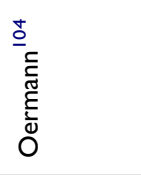 & $\stackrel{\underline{o}}{\underline{\Xi}}_{\underline{\Xi}}$ & 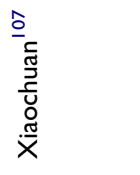 & 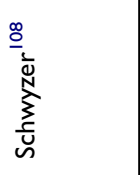 & 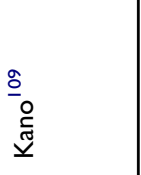 & 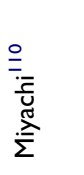 \\
\hline ঠ્ઁ & $\bar{i}$ & $\bar{i}$ & $\frac{0}{2}$ & $\frac{n}{2}$ & $\frac{\text { nn }}{\grave{D}}$ & $\frac{n}{2}$ & $\stackrel{ }{\grave{N}}$ & 곡 & ষ্ণ \\
\hline
\end{tabular}


Table 4 Literature Review On Outcomes Of ARUBA-Eligible Patients (Studies With $\geq 100$ patients)

\begin{tabular}{|c|c|c|c|c|c|c|c|}
\hline Year & Author & $\mathbf{N}$ & $\begin{array}{l}\text { Median } \\
\text { Follow-Up } \\
\text { Period (m) }\end{array}$ & $\begin{array}{l}\text { Median } \\
\text { Age At } \\
\text { GKRS (y) }\end{array}$ & $\begin{array}{l}\text { Median } \\
\text { Nidus } \\
\text { Volume } \\
\text { (mL) }\end{array}$ & $\begin{array}{l}\text { Obliteration } \\
\text { Rate }\end{array}$ & Stroke Or Death Rate \\
\hline 2019 & Karlsson ${ }^{136}$ & $|35|$ & 60 & 41 & 5 & $61 \%(C R)$ & $5.8 \% / 2$ y (stroke), I. $4 \% / 2$ y (death) \\
\hline 2018 & Tonetti $^{134}$ & 233 & 100.8 & $42 *$ & ND & $72 \%(C R)$ & $0.8 \% / y$ \\
\hline 2017 & Ding ${ }^{133}$ & 232 & $90.5 *$ & $42^{*}$ & $2.1 *$ & $72 \% / 5$ y & $10.3 \%$ (CR for stroke or death), I.0\%/y (stroke) \\
\hline 2016 & Ding ${ }^{131}$ & 509 & $86^{*}$ & $40^{*}$ & $3.0^{*}$ & $75 \%(C R)$ & $\begin{array}{l}0.9 \% / y \text { (stroke), } 1.0-2.9 \% \text { (death, depending on } \\
\text { whether the unknown causes of death were } \\
\text { related to AVM or not) }\end{array}$ \\
\hline 2016 & Hanakita ${ }^{135}$ & 240 & 62 & 39 & 4.3 & $73 \% / 6$ y & I.I\%/y (stroke) \\
\hline 2013 & Pollock ${ }^{132}$ & 174 & 64 & 42.5 & 5.6 & $69.7 \%(C R)$ & $10.3 \% / 5$ y (stroke or death) \\
\hline
\end{tabular}

Notes: *Mean.

Abbreviations: ARUBA, A Randomised trial of Unruptured Brain Arteriovenous malformations; CR, crude rate; $m=m o n t h(s)$; GKRS, gamma knife radiosurgery; ND, not described; $y$, year(s).

for future hemorrhage. ${ }^{137,138,141,143,144-146}$ The estimated annual event rates are 7-19\% for DAVFs with CVD and/ or prior hemorrhage, though the rates range from $0-1.5 \%$ in the absence of these aggressive features. ${ }^{137,143,147-149}$ During GKRS, the irradiation target is shunt tissues in the dura mater which can be seen on time-of-flight MRI and DSA. The prescription dose is usually between 18 and 22 Gy in most institutions. Fistula obliteration is achieved in $41-90 \%$ of treated patients after a latency period of several months to years (typically 1-3 years), with an acceptable hemorrhage rate below $5 \%$ as well as low symptomatic RAE rates ranging from $0-5 \% .{ }^{150-164}$ The results of recent studies with significant numbers of study participants $(\geq 20)$ are summarized in Table $5 .^{152-155,157,161-165}$

\section{Unresolved Issues And Future Tasks}

First, no consensus has been reached regarding factors associated with successful obliteration. Knowing those factors would be an important first step to refining appropriate case selection and radiosurgical planning, and to tailoring treatment strategies to individual patients. Several studies have attempted to identify these crucial factors, but to date cavernous sinus location and absence of CVD are the only factors suggested by more than one study. ${ }^{152,154,165,166}$ The inconsistencies among these studies indicate that further investigations are necessary to clarify the relevant issues. Unlike AVM, DAVF is likely to be treated not only with GKRS alone but also in combination with embolization and/or surgery, making it difficult to assess the reasons for failed obliteration after GKRS.
Second, the outcomes of GKRS as a solo treatment remain to be fully elucidated. Due to the latency period in which hemorrhage risk cannot be regarded as negligible, GKRS is generally considered to be an alternative method when endovascular embolization and direct surgery are not feasible or have failed, or for patients with significant medical comorbidities. ${ }^{144}$ As such, in almost all published studies focusing on GKRS for DAVFs, a significant number of patients underwent embolization before GKRS or scheduled embolization immediately after GKRS. Nevertheless, GKRS is more advantageous in terms of safety and minimal invasiveness than the other therapeutic modalities; GKRS alone is thus potentially a good therapeutic option when endeavoring to achieve a balance between efficacy and safety. Indeed, Park et al reported a $90 \%$ obliteration rate with a $0 \%$ hemorrhage rate, suggesting that GKRS might provide acceptable outcomes when used as a solo treatment. ${ }^{163}$ However, their study was based on only 20 patients.

Third, since studies have suggested that cavernous sinus location is associated with fistula obliteration, fistula location may affect radiosurgical outcomes. Taking AVMs as an example, nidus location significantly affects treatment outcomes. $^{16,25,41,49,167}$ To date, however, no study has addressed this issue, probably due to relatively small patient numbers. Starke et al recently reported the first multicenter retrospective analysis of data from 114 patients, approximately half of whom had undergone prior embolization, though they did not show location-specific outcomes, a factor which should be considered in future studies. ${ }^{165}$ 


\begin{tabular}{|c|c|c|c|c|c|c|c|c|c|c|c|c|}
\hline 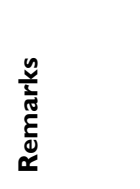 & 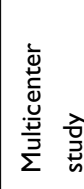 & 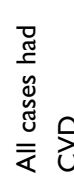 & 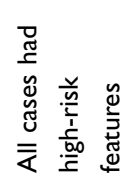 & 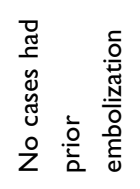 & 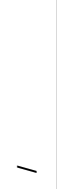 & - & - & - & - & - & & \\
\hline 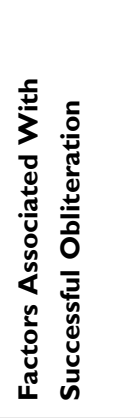 & 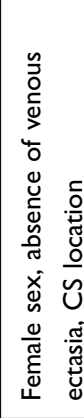 & - & $\begin{array}{l}\stackrel{0}{0} \\
\stackrel{0}{z}\end{array}$ & - & - & 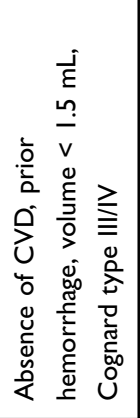 & 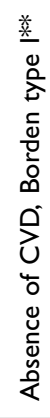 & 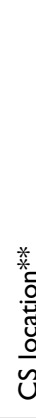 & - & $\frac{d}{2}$ & & \\
\hline 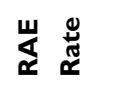 & 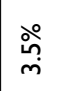 & - & - & ㅇํ & $\stackrel{\circ}{\circ}$ & ळ̊ & 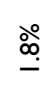 & ஃे & ¿े & वे & & \\
\hline 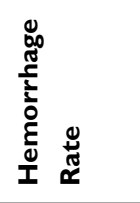 & 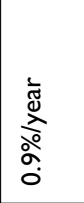 & 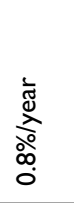 & 离 & ○ㅇ & $\begin{array}{l}\stackrel{0}{0} \\
0 \\
0\end{array}$ & ه̊ & $\stackrel{\circ}{\stackrel{\circ}{\dot{f}}}$ & ओे & वे & वे & & \\
\hline 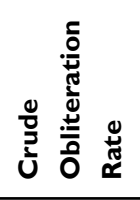 & ळ̊ & ণें & ふેํํ & ఏे & ○̊ㅇㅇ & ڤั่ & ఫें & $\stackrel{\circ}{\stackrel{\circ}{~}}$ & $\stackrel{d}{\partial}$ & $\frac{d}{\partial}$ & & \\
\hline 总 & ஸे & ○े & ஓें & ○े̊ & $\begin{array}{l}\text { t. } \\
\text { bे }\end{array}$ & ळ̊ & $\frac{\circ}{\wedge}$ & ذั่ & ঃ & ì & & \\
\hline 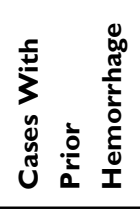 & $\stackrel{\stackrel{\circ}{\sim}}{ }$ & $\frac{\circ}{m}$ & ஓे & ㅇํ & - & ৯̊ & $\stackrel{\circ}{\circ}$ & $\stackrel{\circ}{\varrho}$ & ঃे & वे & & \\
\hline 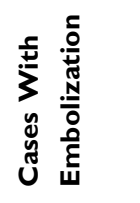 & $\stackrel{\stackrel{\circ}{f}}{\text { fo }}$ & 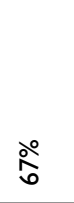 & ふ઼े & ○े & $\stackrel{\circ}{\mathrm{m}}$ & 号 & ڤั่ & ఏ్లे & $\stackrel{2}{2}$ & $\begin{array}{l}+ \\
\stackrel{+}{c} \\
\stackrel{\alpha}{\alpha}\end{array}$ & & \\
\hline 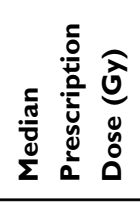 & $\begin{array}{l}\frac{\infty}{N} \\
\text { ī } \\
\stackrel{\tilde{\Phi}}{\Sigma}\end{array}$ & 이 & 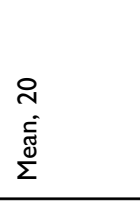 & 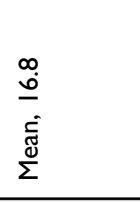 & 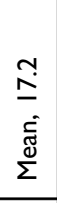 & ㅇ & $\bar{N}$ & $\stackrel{\circ}{\circ}$ & & $\underline{a}$ & & \\
\hline $\mathbf{z}$ & $\stackrel{ \pm}{=}$ & $\mathcal{F}$ & 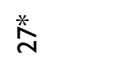 & ㅇ & $\stackrel{+}{\text { N }}$ & $\approx$ & 员 & q & g & $\tilde{a}$ & & \\
\hline 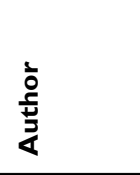 & 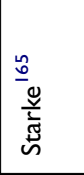 & 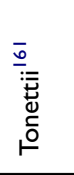 & $\begin{array}{l}\frac{\tilde{\sigma}}{\bar{\sigma}} \\
\stackrel{\bar{v}}{U}\end{array}$ & $\frac{\underline{0}}{\underline{\underline{\underline{k}}}}$ & 总 & 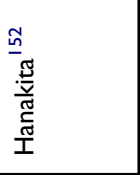 & 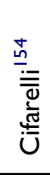 & 㸃 & है & 告 & & \\
\hline ঠ্ & $\frac{\sigma}{\partial}$ & $\frac{\infty}{i}$ & $\frac{\infty}{i}$ & $\frac{0}{2}$ & $\frac{m}{i}$ & $\frac{N}{\grave{N}}$ & 음 & ㄱ. & ¿̊ & $\bar{c}$ & & \\
\hline
\end{tabular}


In conclusion, GKRS has the potential to become a first-line therapeutic option for DAVFs. However, its efficacy must be further confirmed with additional studies based on a large number of participants. Due to the scarcity of cases in a single institution, this goal might be achievable only by conducting a multi-institutional investigation with a large combined sample population. At present, a multi-institutional study is ongoing in Japan (JLGK1802, University Medical Information Network Registry No. UMIN000037211).

\section{GKRS For Cavernous Malformation Current Evidence}

Brain CM is a low-flow and angiographically-occult vascular lesion, accounting for $10 \%$ to $15 \%$ of all brain vascular malformations. ${ }^{168-170} \mathrm{~A} \mathrm{CM}$ becomes symptomatic when it bleeds and expands or causes seizures. In general, the hemorrhage rate for those in deep locations (for brainstem, thalamus, and basal ganglia lesions, the hemorrhage rate is $3-10 \%$ /year) exceeds that for $\mathrm{CM}$ in lobar locations ( $0-12 \% /$ year), and the rate for those with prior hemorrhage (5-23\%/year) is higher than that for $\mathrm{CM}$ without prior bleeding (0-1\%/year). ${ }^{171-177}$ The 5-year risk of additional hemorrhage or neurological decline for those with a prior hemorrhage is high, up to $42 \%$ if untreated, though the risk diminishes over time. ${ }^{178}$

Asymptomatic $\mathrm{CMs}$ are better managed conservatively since the risk of a first-ever intracranial hemorrhage is low and functional impairment from the hemorrhage would be mild; only patients with symptomatic and/or progressive lesions are regarded as good candidates for interventions. ${ }^{170,178-180}$ Surgical resection is recommended for superficial lesions; whereas radiosurgery is considered for those located deep inside the brain, such as lesions in the basal ganglia, thalamus, and brainstem. ${ }^{169,170,179}$

Before the early 2000s, mainly high radiosurgical doses ( $\approx 18 \mathrm{~Gy}$ ) were used, which contributed to a relatively high rate of RAEs. ${ }^{181-184}$ Currently, low doses ( $\leq 15$ Gy) are generally preferred, and provide a level of effectiveness similar to that of higher doses but with a lower risk profile (Table 6). ${ }^{181,185-195}$

The goal of GKRS is to minimize the risk of bleeding, which can be achieved within an approximately two-year latency period. The short- to mid-term outcomes up to $\approx 5$ years are well-known. Recent retrospective studies have shown the post-radiosurgical hemorrhage rates to range from 3.3-15\%/year within two years after GKRS and $0.8-4.7 \%$ /year thereafter (Table 2), a remarkable reduction compared to the pre-radiosurgical hemorrhage rates ranging from $20-40 \% .{ }^{181,185-195}$ The histopathological responses following GKRS are not yet fully understood. Based on the best of currently available evidence, GKRS induces collagen formation, vessel wall-thickening, thrombus formation, and hyalinization in $\mathrm{CM}$ sinusoids, which then develop over the course of several months to a few years. ${ }^{196-198}$ These changes can be accompanied by some areas of neovascularization, which might be responsible for post-radiosurgical hemorrhage and raise the concerns discussed below. ${ }^{198}$

\section{Unresolved Issues And Future Tasks}

First, the optimal radiosurgical dose for CMs has not as yet been standardized, with the mean prescription doses ranging from 11 and 16 Gy (Table 6). ${ }^{181,185-195}$ Reflecting this, the dose-volume response also has not been clarified. These two issues are rather challenging because, unlike AVMs, there would be little visible or apparent change allowing clinicians to determine whether GKRS is effective. The only measurable therapeutic outcome is the hemorrhage rate.

Second, long-term efficacy has not been adequately examined. It seems that GKRS cannot completely eliminate the hemorrhage risk. To date, three studies have attempted to address this issue, ${ }^{186,194,195}$ of which the one with the longest follow-up (mean, 9.3 years) ${ }^{186}$ showed a post-radiosurgical hemorrhage rate for the first 5 years of $1.5-3.3 \%$ /year, apparently much better than the natural history documented in a prospective study ${ }^{178}$ (the rate of hemorrhage or neurological event; $20 \%$ /year during the first year, $12-13 \% / y e a r$ during the second to third years, and 5\%/year during the fourth to fifth years), while a mild increase up to $4.6 \% /$ year was noted after 5 years. These data underscore the importance of conducting further research, with larger patient populations and longer follow-up periods, to define the long-term efficacy of GKS.

\section{Conclusion}

GKRS is highly effective for small to medium-sized AVMs. VSGKRS and a combination of embolization and GKRS are currently being developed as therapeutic options for larger AVMs. These approaches require additional evaluation with larger sample sizes and longer follow-up periods. GKRS for DAVF is feasible as a 


\begin{tabular}{|c|c|c|c|c|c|c|c|c|c|c|c|}
\hline 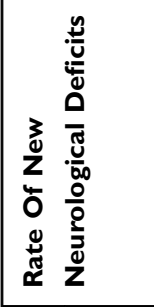 & $\stackrel{\circ}{\circ}$ & よ̊ & $\S$ & $\stackrel{\circ}{\text { ¡े }}$ & $\stackrel{\circ}{\stackrel{\circ}{0}}$ & $\frac{\circ}{\dot{\sigma}}$ & $\stackrel{\circ}{\dot{+}}$ & $\stackrel{\circ}{\stackrel{\rho}{N}}$ & 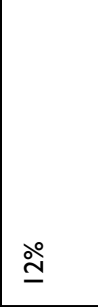 & స్లి & $\stackrel{\circ}{\stackrel{\circ}{~}}$ \\
\hline 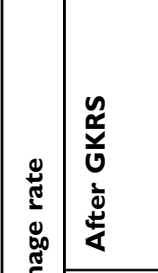 & 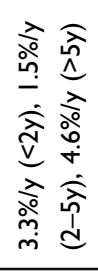 & $\stackrel{\widehat{\partial}}{\stackrel{\circ}{+}}$ & ํํํ & 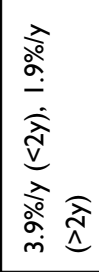 & 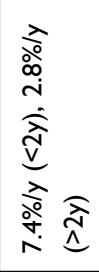 & 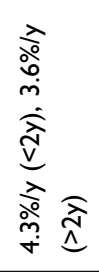 & 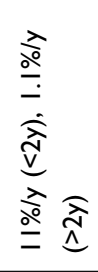 & 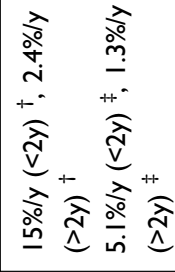 & 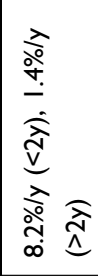 & 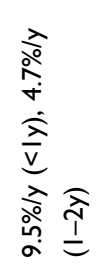 & 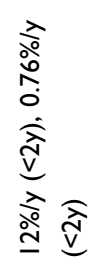 \\
\hline 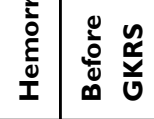 & 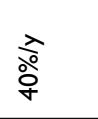 & $\frac{\widehat{\lambda}}{\mathrm{O}}$ & $\S$ & 총 & $\frac{\grave{\partial}}{\stackrel{0}{N}}$ & $\frac{\frac{\lambda}{0}}{m}$ & 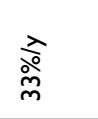 & 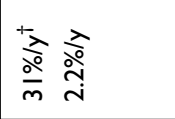 & 斊 & $\Sigma$ & 希 \\
\hline 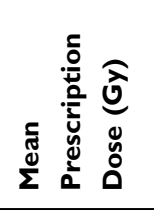 & $\underline{m}$ & 美 & \pm & $\simeq$ & $\underline{n}$ & $=$ & 美 & $\simeq$ & $\underline{\bullet}$ & $\underline{m}$ & $\underline{\varrho}$ \\
\hline لَّ & $\tilde{\infty}$ & ఋ్ & 安 & $\widetilde{\infty}$ & 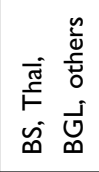 & $\check{\infty}$ & 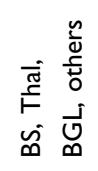 & 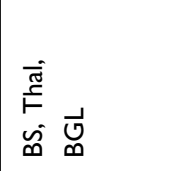 & $\mathscr{\infty}$ & 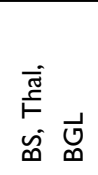 & 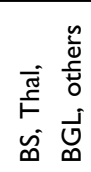 \\
\hline 胥 & $\stackrel{\infty}{-}$ & $\begin{array}{l}\text { : } \\
\text { : } \\
0 \\
0\end{array}$ & $\stackrel{\circ}{-}$ & $\stackrel{+}{*}$ & $\ll$ & $\stackrel{\sim}{m}$ & $\stackrel{\text { 盖 }}{-}$ & 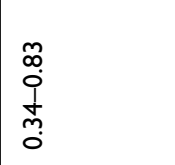 & $\stackrel{\sim}{\longrightarrow}$ & 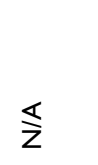 & $\underline{a}$ \\
\hline 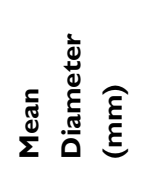 & $\S$ & 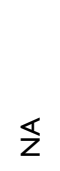 & $\S$ & $\S$ & $\underline{\underline{n}}$ & శె & $\S$ & $\S$ & $\S$ & \pm & $\S$ \\
\hline 師 & $\hat{m}$ & $\mathcal{F}$ & 㝏 & $\mathcal{F}$ & 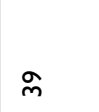 & 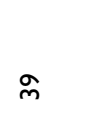 & 㝏 & $\hat{m}$ & $\bar{\sigma}$ & $\stackrel{\infty}{m}$ & $\stackrel{\infty}{m}$ \\
\hline 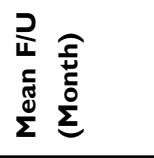 & $\cong$ & $\S$ & 关 & $\stackrel{\circ}{m}$ & $\stackrel{\infty}{\infty}$ & $\bar{\sigma}$ & 萗 & $\stackrel{\infty}{+}$ & ชิ & 㶽 & ติ \\
\hline $\mathbf{z}$ & ஜ & $\stackrel{\circ}{\circ}$ & $\bar{\infty}$ & $\stackrel{q}{q}$ & $\stackrel{\infty}{\stackrel{\infty}{\sim}}$ & 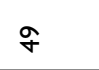 & $\underline{\underline{0}}$ & $\stackrel{m}{=}$ & థ̊ & ఏ & డు \\
\hline 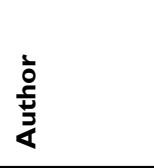 & 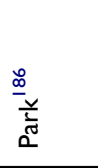 & 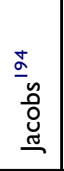 & 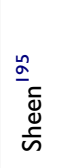 & $\stackrel{\widehat{\omega}}{: \Xi}$ & 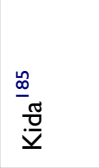 & $\stackrel{\stackrel{\infty}{\Phi}}{\stackrel{\Xi}{\Xi}}$ & $\begin{array}{l}\frac{8}{0} \\
\frac{0}{0} \\
\frac{0}{n} \\
\frac{5}{3}\end{array}$ & $\begin{array}{l}\bar{\sigma} \\
\overline{\widehat{\widehat{D}}} \\
\tilde{z}\end{array}$ & 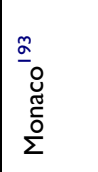 & $\begin{array}{l}\frac{\sigma}{\sigma} \\
\frac{\sigma}{\underline{\sigma}}\end{array}$ & 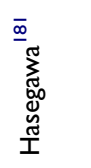 \\
\hline 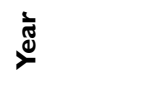 & $\frac{\infty}{a}$ & $\frac{\infty}{a}$ & $\frac{\infty}{a}$ & $\frac{0}{a}$ & $\frac{n}{i}$ & $\stackrel{\sim}{\sim}$ & 음 & 음 & 음 & ठ̊. & ర్రి \\
\hline
\end{tabular}


minimally invasive option but further multicenter studies are needed to both clarify efficacy as a solo treatment modality and confirm factors required for successful obliteration, as well as to examine location-specific outcomes. GKRS for CMs is also feasible for obtaining short- to mid-term prevention of additional hemorrhage. Further long-term follow-up studies are necessary to identify the long-term benefits of GKRS and optimize radiosurgical doses.

\section{Disclosure}

The authors report no conflicts of interest in this work.

\section{References}

1. Leksell DG. Stereotactic radiosurgery. Present status and future trends. Neurol Res. 1987;9(2):60-68. doi:10.1080/01616412.1987.11739775

2. Leksell L. Stereotactic radiosurgery. J Neurol Neurosurg Psychiatry. 1983;46(9):797-803. doi:10.1136/jnnp.46.9.797

3. Massager N, Maris C, Nissim O, Devriendt D, Salmon I, Levivier M. Experimental analysis of radiation dose distribution in radiosurgery. II. Dose fall-off outside the target volume. Stereotact Funct Neurosurg. 2009;87(3):137-142. doi:10.1159/000209293

4. Semwal MK, Singh S, Sarin A, Bhatnagar S, Pathak HC. Comparative clinical dosimetry with X-knife and gamma knife. Phys Med. 2012;28(3):269-272. doi:10.1016/j.ejmp.2011.07.003

5. Steiner L, Forster D, Leksell L, Meyerson BA, Boethius J. Gammathalamotomy in intractable pain. Acta Neurochir (Wien). 1980;52(3-4):173-184. doi:10.1007/BF01402072

6. Leksell L. Cerebral radiosurgery. I. Gammathalamotomy in two cases of intractable pain. Acta Chir Scand. 1968;134(8):585-595.

7. Niranjan A, Lunsford LD. Radiosurgery: where we were, are, and may be in the third millennium. Neurosurgery. 2000;46(3):531543. doi:10.1097/00006123-200003000-00002

8. Fleetwood IG, Steinberg GK. Arteriovenous malformations. Lancet. 2002;359(9309):863-873. doi:10.1016/S0140-6736(02)07946-1

9. Stapf C, Mohr JP, Pile-Spellman J, Solomon RA, Sacco RL, Connolly ES. Epidemiology and natural history of arteriovenous malformations. Neurosurg Focus. 2001;11(5):e1. doi:10.3171/foc.2001.11.5.2

10. Ogilvy CS, Stieg PE, Awad I, et al. AHA Scientific Statement: recommendations for the management of intracranial arteriovenous malformations: a statement for healthcare professionals from a special writing group of the Stroke Council, American Stroke Association. Stroke. 2001;32(6):1458-1471. doi:10.1161/01.STR.32.6.1458

11. Fukuda K, Majumdar M, Masoud H, et al. Multicenter assessment of morbidity associated with cerebral arteriovenous malformation hemorrhages. J Neurointerv Surg. 2017;9(7):664-668. doi:10.1136/ neurintsurg-2016-012485

12. Solomon RA, Connolly ES Jr. Arteriovenous malformations of the brain. $N$ Engl J Med. 2017;376(19):1859-1866. doi:10.1056/ NEJMra1607407

13. Choi JH, Mohr JP. Brain arteriovenous malformations in adults. Lancet Neurol. 2005;4(5):299-308. doi:10.1016/S1474-4422(05) 70073-9

14. Friedlander RM. Clinical practice. Arteriovenous malformations of the brain. $N$ Engl J Med. 2007;356(26):2704-2712. doi:10.1056/ NEJMcp067192

15. Starke RM, Kano H, Ding D, et al. Stereotactic radiosurgery for cerebral arteriovenous malformations: evaluation of long-term outcomes in a multicenter cohort. $J$ Neurosurg. 2017;126(1):36-44. doi:10.3171/2015.9.JNS151311
16. Pollock BE, Flickinger JC, Lunsford LD, Maitz A, Kondziolka D Factors associated with successful arteriovenous malformation radiosurgery. Neurosurgery. 1998;42(6):1239-1244. discussion 1244-1237. doi:10.1097/00006123-199806000-00020

17. Pollock BE, Flickinger JC. A proposed radiosurgery-based grading system for arteriovenous malformations. J Neurosurg. 2002;96 (1):79-85. doi:10.3171/jns.2002.96.1.0079

18. Flickinger JC, Kondziolka D, Maitz AH, Lunsford LD. An analysis of the dose-response for arteriovenous malformation radiosurgery and other factors affecting obliteration. Radiother Oncol. 2002;63 (3):347-354. doi:10.1016/S0167-8140(02)00103-2

19. Liscák R, Vladyka V, Simonová G, et al. Arteriovenous malformations after Leksell gamma knife radiosurgery: rate of obliteration and complications. Neurosurgery. 2007;60(6):1005-1014. discussion 1015-1006. doi:10.1227/01.NEU.0000255474.60505.4A

20. Kano H, Lunsford LD, Flickinger JC, et al. Stereotactic radiosurgery for arteriovenous malformations, Part 1: management of Spetzler-Martin Grade I and II arteriovenous malformations. $J$ Neurosurg. 2012;116(1):11-20. doi:10.3171/2011.9.JNS101740

21. Fokas E, Henzel M, Wittig A, Grund S, Engenhart-Cabillic R. Stereotactic radiosurgery of cerebral arteriovenous malformations: long-term follow-up in 164 patients of a single institution. $J$ Neurol. 2013;260(8):2156-2162.

22. Kano H, Flickinger JC, Yang HC, et al. Stereotactic radiosurgery for Spetzler-Martin Grade III arteriovenous malformations. J Neurosurg. 2014;120(4):973-981. doi:10.3171/2013.12.JNS131600

23. Pollock BE, Kondziolka D, Flickinger JC, Patel AK, Bissonette DJ, Lunsford LD. Magnetic resonance imaging: an accurate method to evaluate arteriovenous malformations after stereotactic radiosurgery. J Neurosurg. 1996;85(6):1044-1049. doi:10.3171/jns. 1996. 85.6.1044

24. Lee CC, Reardon MA, Ball BZ, et al. The predictive value of magnetic resonance imaging in evaluating intracranial arteriovenous malformation obliteration after stereotactic radiosurgery. J Neurosurg. 2015;123 (1):136-144. doi:10.3171/2014.10.JNS141565

25. Starke RM, Yen CP, Ding D, Sheehan JP. A practical grading scale for predicting outcome after radiosurgery for arteriovenous malformations: analysis of 1012 treated patients. J Neurosurg. 2013;119(4):981-987. doi:10.3171/2013.5.JNS1311

26. Starke RM, Ding D, Kano H, et al. International multicenter cohort study of pediatric brain arteriovenous malformations. Part 2: outcomes after stereotactic radiosurgery. J Neurosurg Pediatr. 2017;19 (2):136-148. doi:10.3171/2016.9.PEDS16284

27. Hasegawa H, Hanakita S, Shin M, et al. Does advanced age affect the outcomes of stereotactic radiosurgery for cerebral arteriovenous malformation? World Neurosurg. 2018;109:e715-e723. doi:10.10 16/j.wneu.2017.10.071

28. Ding D, Xu Z, Yen CP, Starke RM, Sheehan JP. Radiosurgery for cerebral arteriovenous malformations in elderly patients: effect of advanced age on outcomes after intervention. World Neurosurg. 2015;84(3):795-804. doi:10.1016/j.wneu.2015.05.012

29. Ding D, Yen CP, Starke RM, Xu Z, Sheehan JP. Effect of prior hemorrhage on intracranial arteriovenous malformation radiosurgery outcomes. Cerebrovasc Dis. 2015;39(1):53-62. doi:10.1159/ 000369959

30. Lunsford LD, Kondziolka D, Flickinger JC, et al. Stereotactic radiosurgery for arteriovenous malformations of the brain. $J$ Neurosurg. 1991;75(4):512-524.

31. Pollock BE, Flickinger JC, Lunsford LD, Bissonette DJ, Kondziolka D. Factors that predict the bleeding risk of cerebral arteriovenous malformations. Stroke. 1996;27(1):1-6. doi:10.1161/ 01.STR.27.1.1

32. Karlsson B, Lindquist C, Steiner L. Prediction of obliteration after gamma knife surgery for cerebral arteriovenous malformations. Neurosurgery. 1997;40(3):425-430. discussion 430-421. doi:10.10 97/00006123-199703000-00001 
33. Schwartz M, Sixel K, Young C, et al. Prediction of obliteration of arteriovenous malformations after radiosurgery: the obliteration prediction index. Can J Neurol Sci. 1997;24(2):106-109. doi: $10.1017 / \mathrm{S} 0317167100021417$

34. Flickinger JC, Kondziolka D, Maitz AH, Lunsford LD. Analysis of neurological sequelae from radiosurgery of arteriovenous malformations: how location affects outcome. Int $J$ Radiat Oncol Biol Phys. 1998;40(2):273-278. doi:10.1016/S0360-3016(97)00718-9

35. Ellis TL, Friedman WA, Bova FJ, Kubilis PS, Buatti JM. Analysis of treatment failure after radiosurgery for arteriovenous malformations. $J$ Neurosurg. 1998;89(1):104-110. doi:10.3171/jns.1998.89.1.0104

36. Gallina P, Merienne L, Meder JF, Schlienger M, Lefkopoulos D, Merland JJ. Failure in radiosurgery treatment of cerebral arteriovenous malformations. Neurosurgery. 1998;42(5):996-1002. discussion 1002-1004. doi:10.1097/00006123-199805000-00024

37. Kwon Y, Jeon SR, Kim JH, et al. Analysis of the causes of treatment failure in gamma knife radiosurgery for intracranial arteriovenous malformations. J Neurosurg. 2000;93(Suppl 3):104106. doi:10.3171/jns.2000.93.supplement 3.0104

38. Shin M, Kawamoto S, Kurita H, et al. Retrospective analysis of a 10-year experience of stereotactic radio surgery for arteriovenous malformations in children and adolescents. $J$ Neurosurg. 2002;97 (4):779-784. doi:10.3171/jns.2002.97.4.0779

39. Pollock BE, Gorman DA, Coffey RJ. Patient outcomes after arteriovenous malformation radiosurgical management: results based on a 5- to 14-year follow-up study. Neurosurgery. 2003;52(6):1291-1296. discussion 1296-1297. doi:10.1227/01.NEU.0000064800.26214.FE

40. Pan DH, Kuo YH, Guo WY, et al. Gamma Knife surgery for cerebral arteriovenous malformations in children: a 13-year experience. $J$ Neurosurg Pediatr. 2008;1(4):296-304. doi:10.3171/PED/ 2008/1/4/296

41. Wegner RE, Oysul K, Pollock BE, et al. A modified radiosurgerybased arteriovenous malformation grading scale and its correlation with outcomes. Int J Radiat Oncol Biol Phys. 2011;79(4):11471150. doi:10.1016/j.ijrobp.2009.12.056

42. Nicolato A, Longhi M, Tommasi N, et al. Leksell Gamma Knife for pediatric and adolescent cerebral arteriovenous malformations: results of 100 cases followed up for at least 36 months. $J$ Neurosurg Pediatr. 2015;16(6):736-747. doi:10.3171/2015.4.PEDS 158

43. Hanakita S, Koga T, Shin M, Igaki H, Saito N. The long-term outcomes of radiosurgery for arteriovenous malformations in pediatric and adolescent populations. $J$ Neurosurg Pediatr. 2015;16(2):222-231. doi:10.3171/2015.1.PEDS14407

44. Pandey P, Marks MP, Harraher CD, et al. Multimodality management of Spetzler-Martin Grade III arteriovenous malformations. $J$ Neurosurg. 2012;116(6):1279-1288. doi:10.3171/2012.3.JNS11 1575

45. Shin M, Maruyama K, Kurita H, et al. Analysis of nidus obliteration rates after gamma knife surgery for arteriovenous malformations based on long-term follow-up data: the University of Tokyo experience. $J$ Neurosurg. 2004;101(1):18-24. doi:10.3171/jns.20 04.101.1.0018

46. Ganz JC, Reda WA, Abdelkarim K. Adverse radiation effects after Gamma Knife Surgery in relation to dose and volume. Acta Neurochir (Wien). 2009;151(1):9-19. doi:10.1007/s00701-008-01 74-4

47. Flickinger JC, Lunsford LD, Kondziolka D, et al. Radiosurgery and brain tolerance: an analysis of neurodiagnostic imaging changes after gamma knife radiosurgery for arteriovenous malformations. Int J Radiat Oncol Biol Phys. 1992;23(1):19-26. doi:10.1016/03603016(92)90539-T

48. Flickinger JC, Kondziolka D, Lunsford LD, et al. A multi-institutional analysis of complication outcomes after arteriovenous malformation radiosurgery. Int J Radiat Oncol Biol Phys. 1999;44 (1):67-74. doi:10.1016/S0360-3016(98)00518-5
49. Flickinger JC, Kondziolka D, Lunsford LD, et al. Development of a model to predict permanent symptomatic postradiosurgery injury for arteriovenous malformation patients. Arteriovenous Malformation Radiosurgery Study Group. Int J Radiat Oncol Biol Phys. 2000;46(5):1143-1148. doi:10.1016/S0360-3016(99)00513-1

50. Cohen-Inbar O, Lee CC, Xu Z, Schlesinger D, Sheehan JP. A quantitative analysis of adverse radiation effects following Gamma Knife radiosurgery for arteriovenous malformations. J Neurosurg. 2015;123 (4):945-953. doi:10.3171/2014.10.JNS142264

51. Yen CP, Matsumoto JA, Wintermark M, et al. Radiation-induced imaging changes following Gamma Knife surgery for cerebral arteriovenous malformations. J Neurosurg. 2013;118(1):63-73. doi:10.3171/2012.10.JNS12402

52. Maruyama K, Kawahara N, Shin M, et al. The risk of hemorrhage after radiosurgery for cerebral arteriovenous malformations. $N \mathrm{Engl}$ $J$ Med. 2005;352(2):146-153. doi:10.1056/NEJMoa040907

53. Pollock BE, Flickinger JC, Lunsford LD, Bissonette DJ, Kondziolka D. Hemorrhage risk after stereotactic radiosurgery of cerebral arteriovenous malformations. Neurosurgery. 1996;38 (4):652-659. discussion 659-661. doi:10.1227/00006123-1996040 00-00004

54. Karlsson B, Lax I, Söderman M. Risk for hemorrhage during the 2year latency period following gamma knife radiosurgery for arteriovenous malformations. Int J Radiat Oncol Biol Phys. 2001;49 (4):1045-1051. doi:10.1016/S0360-3016(00)01432-2

55. Friedman WA, Blatt DL, Bova FJ, Buatti JM, Mendenhall WM, Kubilis PS. The risk of hemorrhage after radiosurgery for arteriovenous malformations. $J$ Neurosurg. 1996;84(6):912-919. doi:10. 3171/jns.1996.84.6.0912

56. Shin M, Kawahara N, Maruyama K, Tago M, Ueki K, Kirino T. Risk of hemorrhage from an arteriovenous malformation confirmed to have been obliterated on angiography after stereotactic radiosurgery. J Neurosurg. 2005;102(5):842-846. doi:10.3171/jns.2005. 102.5.0842

57. Lindqvist M, Karlsson B, Guo WY, Kihlström L, Lippitz B, Yamamoto M. Angiographic long-term follow-up data for arteriovenous malformations previously proven to be obliterated after gamma knife radiosurgery. Neurosurgery. 2000;46 (4):803-808. discussion 809-810. doi:10.1097/00006123-20000 4000-00006

58. Szeifert GT, Salmon I, Baleriaux D, Brotchi J, Levivier M. Immunohistochemical analysis of a cerebral arteriovenous malformation obliterated by radiosurgery and presenting with re-bleeding. Case report. Neurol Res. 2003;25(7):718-721. doi:10.1179/0161 64103101202228

59. Kurita H, Sasaki T, Kawamoto S, et al. Chronic encapsulated expanding hematoma in association with gamma knife stereotactic radiosurgery for a cerebral arteriovenous malformation. Case report. J Neurosurg. 1996;84(5):874-878. doi:10.3171/jns.1996.84.5.0874

60. Shuto T, Matsunaga S, Suenaga J. Surgical treatment for late complications following gamma knife surgery for arteriovenous malformations. Stereotact Funct Neurosurg. 2011;89(2):96-102. doi:10.1159/000323543

61. Shuto T, Yagishita S, Matsunaga S. Pathological characteristics of cyst formation following gamma knife surgery for arteriovenous malformation. Acta Neurochir (Wien). 2015;157(2):293-298. doi:10. 1007/s00701-014-2298-z

62. Parkhutik V, Lago A, Aparici F, et al. Late clinical and radiological complications of stereotactical radiosurgery of arteriovenous malformations of the brain. Neuroradiology. 2013;55(4):405-412. doi:10.1007/s00234-012-1115-8

63. Izawa M, Hayashi $M$, Chernov $M$, et al. Long-term complications after gamma knife surgery for arteriovenous malformations. $J$ Neurosurg. 2005;102(s_supplement):34-37. doi:10.3171/sup.2005. 102.s_supplement.0034 
64. Hasegawa H, Hanakita S, Shin M, et al. A comprehensive study of symptomatic late radiation-induced complications after radiosurgery for brain arteriovenous malformation: incidence, risk factors, and clinical outcomes. World Neurosurg. 2018;116:e556-e565. doi:10.1016/j.wneu.2018.05.038

65. Ilyas A, Chen CJ, Ding D, et al. Cyst formation after stereotactic radiosurgery for brain arteriovenous malformations: a systematic review. J Neurosurg. 2017;1-10.

66. Pomeraniec IJ, Ding D, Starke RM, et al. Delayed cyst formation after stereotactic radiosurgery for brain arteriovenous malformations. J Neurosurg. 2017;1-10.

67. Matsuo T, Kamada K, Izumo T, Hayashi N, Nagata I. Cyst formation after linac-based radiosurgery for arteriovenous malformation: examination of predictive factors using magnetic resonance imaging. Clin Neurol Neurosurg. 2014;121:10-16. doi:10.1016/j. clineuro.2014.03.006

68. Pollock BE, Link MJ, Branda ME, Storlie CB. Incidence and management of late adverse radiation effects after arteriovenous malformation radiosurgery. Neurosurgery. 2017. doi:10.1093/neuros/nyx010

69. Kano H, Flickinger JC, Tonetti D, et al. Estimating the risks of adverse radiation effects after gamma knife radiosurgery for arteriovenous malformations. Stroke. 2017;48(1):84-90. doi:10.1161/ STROKEAHA.116.014825

70. Yamamoto M, Jimbo M, Hara M, Saito I, Mori K. Gamma knife radiosurgery for arteriovenous malformations: long-term follow-up results focusing on complications occurring more than 5 years after irradiation. Neurosurgery. 1996;38(5):906-914. doi:10.1097/000 06123-199605000-00010

71. Yamamoto M, Hara M, Ide M, Ono Y, Jimbo M, Saito I. Radiationrelated adverse effects observed on neuro-imaging several years after radiosurgery for cerebral arteriovenous malformations. Surg Neurol. 1998;49(4):385-397. discussion 397-388. doi:10.1016/ S0090-3019(97)00531-4

72. Hasegawa $T$, Kato $T$, Naito $T$, et al. Long-term outcomes for pediatric patients with brain arteriovenous malformations treated with gamma knife radiosurgery, Part 2: the incidence of cyst formation, encapsulated hematoma, and radiation-induced tumor. World Neurosurg. 2019;126:e1526-e1536. doi:10.1016/j.wneu.20 19.03.177

73. Nakajima H, Yamanaka K, Ishibashi K, Iwai Y. Delayed cyst formations and/or expanding hematomas developing after Gamma Knife surgery for cerebral arteriovenous malformations. J Clin Neurosci. 2016;33:96-99. doi:10.1016/j.jocn.2016.01.044

74. Pan HC, Sheehan J, Stroila M, Steiner M, Steiner L. Late cyst formation following gamma knife surgery of arteriovenous malformations. J Neurosurg. 2005;102(s_supplement):124-127. doi:10.3171/jns.2005.102.s_supplement.0124

75. Xhumari A, Rroji A, Enesi E, Bushati T, Sallabanda Diaz K, Petrela M. Glioblastoma after AVM radiosurgery. Case report and review of the literature. Acta Neurochir (Wien). 2015;157(5):889895. doi:10.1007/s00701-015-2377-9

76. Patel TR, Chiang VL. Secondary neoplasms after stereotactic radiosurgery. World Neurosurg. 2014;81(3-4):594-599. doi:10.10 16/j.wneu.2013.10.043

77. Yoshida K, Ichikawa T, Kurozumi K, Yanai H, Onoda K, Date I. Fatal glioblastoma after Gamma Knife radiosurgery for arteriovenous malformation in a child. J Clin Neurosci. 2014;21(8):14531455. doi:10.1016/j.jocn.2013.10.039

78. Berman EL, Eade TN, Brown D, et al. Radiation-induced tumor after stereotactic radiosurgery for an arteriovenous malformation: case report. Neurosurgery. 2007;61(5):E1099. discussion E1099. doi:10.1227/01.neu.0000303207.92617.4e

79. Kaido T, Hoshida T, Uranishi R, et al. Radiosurgery-induced brain tumor. Case report. J Neurosurg. 2001;95(4):710-713. doi:10.3171/ jns.2001.95.4.0710
80. Hasegawa H, Hanakita S, Shin M, et al. Re-evaluation of the size limitation in single-session stereotactic radiosurgery for brain arteriovenous malformations: detailed analyses on the outcomes with focusing on radiosurgical doses. Neurosurgery. 2019. doi:10.1093/ neuros/nyz280

81. Chung WY, Shiau CY, Wu HM, et al. Staged radiosurgery for extra-large cerebral arteriovenous malformations: method, implementation, and results. J Neurosurg. 2008;109(Suppl):65-72. doi: $10.3171 / \mathrm{JNS} / 2008 / 109 / 12 / \mathrm{S} 11$

82. Ding C, Solberg TD, Hrycushko B, Medin P, Whitworth L, Timmerman RD. Multi-staged robotic stereotactic radiosurgery for large cerebral arteriovenous malformations. Radiother Oncol. 2013;109(3):452-456. doi:10.1016/j.radonc.2013.07.018

83. Firlik AD, Levy EI, Kondziolka D, Yonas H. Staged volume radiosurgery followed by microsurgical resection: a novel treatment for giant cerebral arteriovenous malformations: technical case report. Neurosurgery. 1998;43(5):1223-1228. doi:10.1097/00006123-1998 11000-00124

84. Kano H, Kondziolka D, Flickinger JC, et al. Stereotactic radiosurgery for arteriovenous malformations, Part 6: multistaged volumetric management of large arteriovenous malformations. $J$ Neurosurg. 2012;116(1):54-65. doi:10.3171/2011.9.JNS11177

85. Ilyas A, Chen CJ, Ding D, et al. Volume-staged versus dose-staged stereotactic radiosurgery outcomes for large brain arteriovenous malformations: a systematic review. J Neurosurg. 2018;128 (1):154-164. doi:10.3171/2016.9.JNS161571

86. Moosa S, Chen CJ, Ding D, et al. Volume-staged versus dosestaged radiosurgery outcomes for large intracranial arteriovenous malformations. Neurosurg Focus. 2014;37(3):E18. doi:10.3171/ 2014.5.FOCUS14205

87. Pollock BE, Kline RW, Stafford SL, Foote RL, Schomberg PJ. The rationale and technique of staged-volume arteriovenous malformation radiosurgery. Int J Radiat Oncol Biol Phys. 2000;48(3):817824. doi:10.1016/S0360-3016(00)00696-9

88. Sirin S, Kondziolka D, Niranjan A, Flickinger JC, Maitz AH, Lunsford LD. Prospective staged volume radiosurgery for large arteriovenous malformations: indications and outcomes in otherwise untreatable patients. Neurosurgery. 2006;58(1):17-27. discussion 17-27. doi:10.1227/01.NEU.0000190653.42970.6B

89. Hanakita S, Shin M, Koga T, Igaki H, Saito N. Outcomes of volumestaged radiosurgery for cerebral arteriovenous malformations larger than $20 \mathrm{~cm}(3)$ with more than 3 years of follow-up. World Neurosurg. 2016;87:242-249. doi:10.1016/j.wneu.2015.12.020

90. Nagy G, Grainger A, Hodgson TJ, et al. Staged-volume radiosurgery of large arteriovenous malformations improves outcome by reducing the rate of adverse radiation effects. Neurosurgery. 2016. doi:10.1227/NEU.0000000000001212

91. Lindvall P, Bergstrom P, Lofroth PO, et al. Hypofractionated conformal stereotactic radiotherapy for arteriovenous malformations. Neurosurgery. 2003;53(5):1036-1042. discussion 1042-1033. doi:10.1227/01.NEU.0000088566.82699.E6

92. Laing RW, Childs J, Brada M. Failure of conventionally fractionated radiotherapy to decrease the risk of hemorrhage in inoperable arteriovenous malformations. Neurosurgery. 1992;30(6):872-875. discussion 875-876. doi:10.1227/00006123-199206000-00009

93. Karlsson B, Lindqvist M, Blomgren H, et al. Long-term results after fractionated radiation therapy for large brain arteriovenous malformations. Neurosurgery. 2005;57(1):42-49. discussion 42-49. doi:10.1227/01.NEU.0000163095.56638.26

94. Park HR, Lee JM, Kim JW, et al. Time-staged gamma knife stereotactic radiosurgery for large cerebral arteriovenous malformations: a preliminary report. PLOS ONE. 2016;11(11):e0165783. doi:10.1371/journal.pone.0165783

95. Ilyas A, Chen CJ, Ding D, et al. Volume-staged versus dose-staged stereotactic radiosurgery outcomes for large brain arteriovenous malformations: a systematic review. J Neurosurg. 2017;1-11. 
96. Chytka T, Liscak R, Kozubikova P, Vymazal J. Radiosurgery for large arteriovenous malformations as a single-session or staged treatment. Stereotact Funct Neurosurg. 2015;93(5):342-347. doi: $10.1159 / 000439116$

97. Kano H, Flickinger JC, Nakamura A, et al. How to improve obliteration rates during volume-staged stereotactic radiosurgery for large arteriovenous malformations. J Neurosurg. 2018;1-8.

98. El-Shehaby AMN, Reda WA, Abdel Karim KM, Emad Eldin RM, Nabeel AM, Tawadros SR. Volume-staged Gamma Knife radiosurgery for large brain arteriovenous malformation. World Neurosurg. 2019. doi:10.1016/j.wneu.2019.08.065

99. Franzin A, Panni P, Spatola G, et al. Results of volume-staged fractionated Gamma Knife radiosurgery for large complex arteriovenous malformations: obliteration rates and clinical outcomes of an evolving treatment paradigm. $J$ Neurosurg. 2016;125(Supp1 1):104-113. doi:10.3171/2016.7.GKS161549

100. Huang PP, Rush SC, Donahue B, et al. Long-term outcomes after staged-volume stereotactic radiosurgery for large arteriovenous malformations. Neurosurgery. 2012;71(3):632-643. discussion 643-634. doi:10.1227/NEU.0b013e31825fd247

101. Pollock BE, Link MJ, Stafford SL, Lanzino G, Garces YI, Foote RL. Volume-staged stereotactic radiosurgery for intracranial arteriovenous malformations: outcomes based on an 18-year experience. Neurosurgery. 2017;80(4):543-550. doi:10.1093/neuros/nyw107

102. Seymour ZA, Sneed PK, Gupta N, et al. Volume-staged radiosurgery for large arteriovenous malformations: an evolving paradigm. J Neurosurg. 2016;124(1):163-174. doi:10.3171/2014.12. JNS141308

103. Nagy G, Grainger A, Hodgson TJ, et al. Staged-volume radiosurgery of large arteriovenous malformations improves outcome by reducing the rate of adverse radiation effects. Neurosurgery. 2017;80(2):180-192. doi:10.1227/NEU.0000000000001212

104. Oermann EK, Ding D, Yen CP, et al. Effect of prior embolization on cerebral arteriovenous malformation radiosurgery outcomes: a case-control study. Neurosurgery. 2015;77(3):406-417. discussion 417. doi:10.1227/NEU.0000000000000772

105. Lee CC, Chen CJ, Ball B, et al. Stereotactic radiosurgery for arteriovenous malformations after Onyx embolization: a case-control study. J Neurosurg. 2015;123(1):126-135. doi:10.3171/2014. 12.JNS141437

106. Huo X, Jiang Y, Lv X, Yang H, Zhao Y, Li Y. Gamma Knife surgical treatment for partially embolized cerebral arteriovenous malformations. J Neurosurg. 2015;1-10.

107. Xiaochuan H, Yuhua J, Xianli L, Hongchao Y, Yang Z, Youxiang L. Targeted embolization reduces hemorrhage complications in partially embolized cerebral AVM combined with gamma knife surgery. Interv Neuroradiol. 2015;21(1):80-87. doi:10.1177/INR2014-10090

108. Schwyzer L, Yen CP, Evans A, Zavoian S, Steiner L. Long-term results of gamma knife surgery for partially embolized arteriovenous malformations. Neurosurgery. 2012;71(6):1139-1147. discussion 1147-1138. doi:10.1227/NEU.0b013e3182720280

109. Kano H, Kondziolka D, Flickinger JC, et al. Stereotactic radiosurgery for arteriovenous malformations after embolization: a casecontrol study. J Neurosurg. 2012;117(2):265-275. doi:10.3171/ 2012.4.JNS111935

110. Miyachi S, Negoro M, Okamoto T, et al. Embolisation of cerebral arteriovenous malformations to assure successful subsequent radiosurgery. J Clin Neurosci. 2000;7(Suppl 1):82-85. doi:10.1054/jocn. 2000.0718

111. Miyachi S, Izumi T, Satow T, et al. Effectiveness of preradiosurgical embolization with NBCA for arteriovenous malformations retrospective outcome analysis in a japanese registry of 73 patients (J-REAL study). Neurointervention. 2017;12(2):100-109. doi:10. 5469/neuroint.2017.12.2.100
112. Strauss I, Haim O, Umansky D, et al. Impact of onyx embolization on radiosurgical management of cerebral arteriovenous malformations: treatment and outcome. World Neurosurg. 2017;108:656661. doi:10.1016/j.wneu.2017.08.188

113. Huo X, Jiang Y, Lv X, Yang H, Zhao Y, Li Y. Gamma Knife surgical treatment for partially embolized cerebral arteriovenous malformations. J Neurosurg. 2016;124(3):767-776. doi:10.3171/ 2015.1.JNS142711

114. Back AG, Vollmer D, Zeck O, Shkedy C, Shedden PM. Retrospective analysis of unstaged and staged Gamma Knife surgery with and without preceding embolization for the treatment of arteriovenous malformations. J Neurosurg. 2008;109(Suppl):5764. doi: $10.3171 / \mathrm{JNS} / 2008 / 109 / 12 / \mathrm{S} 10$

115. Yang SY, Kim DG, Chung HT, Paek SH, Park JH, Han DH. Radiosurgery for large cerebral arteriovenous malformations. Acta Neurochir (Wien). 2009;151(2):113-124. doi:10.1007/s00701-0080173-5

116. Nataraj A, Mohamed MB, Gholkar A, et al. Multimodality treatment of cerebral arteriovenous malformations. World Neurosurg. 2014;82(1-2):149-159. doi:10.1016/j.wneu.2013.02.064

117. Darsaut TE, Guzman R, Marcellus ML, et al. Management of pediatric intracranial arteriovenous malformations: experience with multimodality therapy. Neurosurgery. 2011;69(3):540-556. discussion 556. doi:10.1227/NEU.0b013e3182181c00

118. Izawa M, Chernov M, Hayashi M, Iseki H, Hori T, Takakura K. Combined management of intracranial arteriovenous malformations with embolization and gamma knife radiosurgery: comparative evaluation of the long-term results. Surg Neurol. 2009;71 (1):43-52. discussion 52-43. doi:10.1016/j.surneu.2007.11.016

119. Xu F, Zhong J, Ray A, Manjila S, Bambakidis NC. Stereotactic radiosurgery with and without embolization for intracranial arteriovenous malformations: a systematic review and meta-analysis. Neurosurg Focus. 2014;37(3):E16. doi:10.3171/2014.6.FOCUS14 178

120. Andrade-Souza YM, Ramani M, Scora D, Tsao MN, terBrugge K, Schwartz ML. Embolization before radiosurgery reduces the obliteration rate of arteriovenous malformations. Neurosurgery. 2007;60 (3):443-451. discussion 451-442. doi:10.1227/01.NEU.00002553 47.25959.D0

121. Murray G, Brau RH. A 10-year experience of radiosurgical treatment for cerebral arteriovenous malformations: a perspective from a series with large malformations. Clinical article. J Neurosurg. 2011;115(2):337-346. doi:10.3171/2011.3.JNS10814

122. Schlienger M, Atlan D, Lefkopoulos D, et al. Linac radiosurgery for cerebral arteriovenous malformations: results in 169 patients. Int J Radiat Oncol Biol Phys. 2000;46(5):1135-1142. doi:10.1016/ S0360-3016(99)00523-4

123. Mathis JA, Barr JD, Horton JA, et al. The efficacy of particulate embolization combined with stereotactic radiosurgery for treatment of large arteriovenous malformations of the brain. AJNR Am J Neuroradiol. 1995;16(2):299-306.

124. Dawson RC 3rd, Tarr RW, Hecht ST, et al. Treatment of arteriovenous malformations of the brain with combined embolization and stereotactic radiosurgery: results after 1 and 2 years. AJNR Am J Neuroradiol. 1990;11(5):857-864.

125. Akakin A, Ozkan A, Akgun E, et al. Endovascular treatment increases but gamma knife radiosurgery decreases angiogenic activity of arteriovenous malformations: an in vivo experimental study using a rat cornea model. Neurosurgery. 2010;66(1):121-129. discussion 129-130. doi:10.1227/01.NEU.0000363154.88768.34

126. Pollock BE, Kondziolka D, Lunsford LD, Bissonette D, Flickinger JC. Repeat stereotactic radiosurgery of arteriovenous malformations: factors associated with incomplete obliteration. Neurosurgery. 1996;38(2):318-324. doi:10.1097/00006123-199602 000-00016 
127. Shtraus N, Schifter D, Corn BW, et al. Radiosurgical treatment planning of AVM following embolization with Onyx: possible dosage error in treatment planning can be averted. J Neurooncol. 2010;98(2):271-276. doi:10.1007/s11060-010-0177-x

128. Miyawaki L, Dowd C, Wara W, et al. Five year results of LINAC radiosurgery for arteriovenous malformations: outcome for large AVMS. Int J Radiat Oncol Biol Phys. 1999;44(5):1089-1106. doi:10.1016/S0360-3016(99)00102-9

129. Mohr JP, Parides MK, Stapf C, et al. Medical management with or without interventional therapy for unruptured brain arteriovenous malformations (ARUBA): a multicentre, non-blinded, randomised trial. Lancet. 2014;383(9917):614-621. doi:10.1016/S0140-6736 (13) $62302-8$

130. Magro E, Gentric JC, Darsaut TE, et al. Responses to ARUBA: a systematic review and critical analysis for the design of future arteriovenous malformation trials. J Neurosurg. 2017;126(2):486494. doi:10.3171/2015.6.JNS15619

131. Ding D, Starke RM, Kano H, et al. Radiosurgery for cerebral arteriovenous malformations in a randomized trial of unruptured brain Arteriovenous Malformations (ARUBA)-eligible patients: a multicenter study. Stroke. 2016;47(2):342-349. doi:10.1161/ STROKEAHA.115.011400

132. Pollock BE, Link MJ, Brown RD. The risk of stroke or clinical impairment after stereotactic radiosurgery for ARUBA-eligible patients. Stroke. 2013;44(2):437-441. doi:10.1161/STROKEAHA. 112.670232

133. Ding D, Starke RM, Kano H, et al. Stereotactic radiosurgery for ARUBA (A Randomized Trial of Unruptured Brain Arteriovenous Malformations)-Eligible Spetzler-Martin Grade I and II arteriovenous malformations: a multicenter study. World Neurosurg. 2017;102:507-517. doi:10.1016/j.wneu.2017.03.061

134. Tonetti DA, Gross BA, Atcheson KM, et al. The benefit of radiosurgery for ARUBA-eligible arteriovenous malformations: a practical analysis over an appropriate follow-up period. J Neurosurg. 2018;128(6):1850-1854. doi:10.3171/2017.1.JNS162962

135. Hanakita S, Shin M, Koga T, Igaki H, Saito N. Risk reduction of cerebral stroke after stereotactic radiosurgery for small unruptured brain arteriovenous malformations. Stroke. 2016;47(5):1247-1252. doi:10.1161/STROKEAHA.116.013132

136. Karlsson B, Jokura H, Yang HC, et al. The NASSAU (New ASSessment of cerebral Arteriovenous Malformations yet Unruptured) Analysis: are the results from the ARUBA trial also applicable to unruptured arteriovenous malformations deemed suitable for Gamma Knife surgery? Neurosurgery. 2019;85(1):E118 E124. doi:10.1093/neuros/nyy391

137. Soderman M, Pavic L, Edner G, Holmin S, Andersson T. Natural history of dural arteriovenous shunts. Stroke. 2008;39(6):17351739. doi:10.1161/STROKEAHA.107.506485

138. van Dijk JM, Terbrugge KG, Willinsky RA, Wallace MC. The natural history of dural arteriovenous shunts: the toronto experience. Stroke. 2009;40(5):e412. author reply e413-414. doi:10.1161/ STROKEAHA.108.545327

139. Kwon BJ, Han MH, Kang HS, Chang KH. MR imaging findings of intracranial dural arteriovenous fistulas: relations with venous drainage patterns. AJNR Am J Neuroradiol. 2005;26(10):25002507.

140. Hurst RW, Bagley LJ, Galetta S, et al. Dementia resulting from dural arteriovenous fistulas: the pathologic findings of venous hypertensive encephalopathy. AJNR Am J Neuroradiol. 1998;19 (7):1267-1273.

141. Cognard C, Casasco A, Toevi M, Houdart E, Chiras J, Merland JJ. Dural arteriovenous fistulas as a cause of intracranial hypertension due to impairment of cranial venous outflow. J Neurol Neurosurg Psychiatry. 1998;65(3):308-316. doi:10.1136/jnnp.65. 3.308
142. Lasjaunias P, Chiu M, ter Brugge K, Tolia A, Hurth M, Bernstein M. Neurological manifestations of intracranial dural arteriovenous malformations. J Neurosurg. 1986;64(5):724-730. doi:10.3171/ jns.1986.64.5.0724

143. van Dijk JM, terBrugge KG, Willinsky RA, Wallace MC. Clinical course of cranial dural arteriovenous fistulas with long-term persistent cortical venous reflux. Stroke. 2002;33(5):1233-1236. doi:10.1161/01.STR.0000014772.02908.44

144. Gandhi D, Chen J, Pearl M, Huang J, Gemmete JJ, Kathuria S. Intracranial dural arteriovenous fistulas: classification, imaging findings, and treatment. AJNR Am J Neuroradiol. 2012;33 (6):1007-1013. doi:10.3174/ajnr.A2798

145. Borden JA, Wu JK, Shucart WA. A proposed classification for spinal and cranial dural arteriovenous fistulous malformations and implications for treatment. J Neurosurg. 1995;82(2):166-179. doi:10.3171/jns.1995.82.2.0166

146. Cognard C, Gobin YP, Pierot L, et al. Cerebral dural arteriovenous fistulas: clinical and angiographic correlation with a revised classification of venous drainage. Radiology. 1995;194(3):671-680. doi:10.1148/radiology.194.3.7862961

147. Strom RG, Botros JA, Refai D, et al. Cranial dural arteriovenous fistulae: asymptomatic cortical venous drainage portends less aggressive clinical course. Neurosurgery. 2009;64(2):241247. discussion 247-248. doi:10.1227/01.NEU.0000338066.306 65.B2

148. Zipfel GJ, Shah MN, Refai D, Dacey RG Jr., Derdeyn CP. Cranial dural arteriovenous fistulas: modification of angiographic classification scales based on new natural history data. Neurosurg Focus. 2009;26(5):E14. doi:10.3171/2009.2.FOCUS0928

149. Gross BA, Albuquerque FC, McDougall CG, et al. A multi-institutional analysis of the untreated course of cerebral dural arteriovenous fistulas. J Neurosurg. 2018;129(5):1114-1119. doi:10.3171/ 2017.6.JNS171090

150. Pan DH, Wu HM, Kuo YH, Chung WY, Lee CC, Guo WY. Intracranial dural arteriovenous fistulas: natural history and rationale for treatment with stereotactic radiosurgery. Prog Neurol Surg. 2013;27:176-194.

151. Soderman M, Dodoo E, Karlsson B. Dural arteriovenous fistulas and the role of gamma knife stereotactic radiosurgery: the Stockholm experience. Prog Neurol Surg. 2013;27:205217.

152. Hanakita S, Koga T, Shin M, Shojima M, Igaki H, Saito N. Role of Gamma Knife surgery in the treatment of intracranial dural arteriovenous fistulas. $J$ Neurosurg. 2012;117(Suppl):158-163. doi:10. 3171/2012.7.GKS12967

153. Yang HC, Kano H, Kondziolka D, et al. Stereotactic radiosurgery with or without embolization for intracranial dural arteriovenous fistulas. Neurosurgery. 2010;67(5):1276-1283. discussion 1284-1275. doi:10. 1227/NEU.0b013e3181ef3f22

154. Cifarelli CP, Kaptain G, Yen CP, Schlesinger D, Sheehan JP. Gamma knife radiosurgery for dural arteriovenous fistulas. Neurosurgery. 2010;67(5):1230-1235. discussion 1235. doi:10.12 27/NEU.0b013e3181eff6f7

155. Soderman M, Edner G, Ericson K, et al. Gamma knife surgery for dural arteriovenous shunts: 25 years of experience. J Neurosurg. 2006;104(6):867-875. doi:10.3171/jns.2006.104.6.867

156. Pan DH, Chung WY, Guo WY, et al. Stereotactic radiosurgery for the treatment of dural arteriovenous fistulas involving the transverse-sigmoid sinus. $J$ Neurosurg. 2002;96(5):823-829. doi:10.31 71/jns.2002.96.5.0823

157. Friedman JA, Pollock BE, Nichols DA, Gorman DA, Foote RL, Stafford SL. Results of combined stereotactic radiosurgery and transarterial embolization for dural arteriovenous fistulas of the transverse and sigmoid sinuses. J Neurosurg. 2001;94(6):886891. doi:10.3171/jns.2001.94.6.0886 
158. Pollock BE, Nichols DA, Garrity JA, Gorman DA, Stafford SL. Stereotactic radiosurgery and particulate embolization for cavernous sinus dural arteriovenous fistulae. Neurosurgery. 1999;45 (3):459-466. discussion 466-457. doi:10.1097/00006123-199909 000-00008

159. Link MJ, Coffey RJ, Nichols DA, Gorman DA. The role of radiosurgery and particulate embolization in the treatment of dural arteriovenous fistulas. J Neurosurg. 1996;84(5):804-809. doi:10.31 71/jns.1996.84.5.0804

160. Guo WY, Pan DH, Wu HM, et al. Radiosurgery as a treatment alternative for dural arteriovenous fistulas of the cavernous sinus. AJNR Am J Neuroradiol. 1998;19(6):1081-1087.

161. Tonetti DA, Gross BA, Jankowitz BT, et al. Reconsidering an important subclass of high-risk dural arteriovenous fistulas for stereotactic radiosurgery. J Neurosurg. 2018;1-5.

162. Chen CJ, Buell TJ, Diamond J, et al. Stereotactic radiosurgery for high-grade intracranial dural arteriovenous fistulas. World Neurosurg. 2018;116:e640-e648. doi:10.1016/j.wneu.20 18.05.062

163. Park KS, Kang DH, Park SH, Kim YS. The efficacy of gamma knife radiosurgery alone as a primary treatment for intracranial dural arteriovenous fistulas. Acta Neurochir (Wien). 2016;158 (4):821-828. doi:10.1007/s00701-016-2720-9

164. Pan DH, Lee CC, Wu HM, Chung WY, Yang HC, Lin CJ. Gamma Knife radiosurgery for the management of intracranial dural arteriovenous fistulas. Acta Neurochir Suppl. 2013;116:113-119. doi:10.1007/978-3-7091-1376-9_18

165. Starke RM, McCarthy DJ, Chen CJ, et al. Evaluation of stereotactic radiosurgery for cerebral dural arteriovenous fistulas in a multicenter international consortium. J Neurosurg. 2019;1-8.

166. Yang H, Kano H, Kondziolka D, et al. Stereotactic radiosurgery with or without embolization for intracranial dural arteriovenous fistulas. Prog Neurol Surg. 2013;27:195-204.

167. Flickinger JC, Kondziolka D, Pollock BE, Maitz AH, Lunsford LD. Complications from arteriovenous malformation radiosurgery: multivariate analysis and risk modeling. Int J Radiat Oncol Biol Phys. 1997;38(3):485-490. doi:10.1016/S0360-3016(97)89481-3

168. Maraire JN, Awad IA. Intracranial cavernous malformations: lesion behavior and management strategies. Neurosurgery. 1995;37 (4):591-605. doi:10.1227/00006123-199510000-00001

169. Stapleton CJ, Barker FG 2nd. Cranial cavernous malformations: natural history and treatment. Stroke. 2018;49(4):1029-1035. doi:10.1161/STROKEAHA.117.017074

170. Batra S, Lin D, Recinos PF, Zhang J, Rigamonti D. Cavernous malformations: natural history, diagnosis and treatment. Nat Rev Neurol. 2009;5(12):659-670. doi:10.1038/nrneurol.2009.177

171. Dammann P, Jabbarli R, Wittek P, et al. Solitary sporadic cerebral cavernous malformations: risk factors of first or recurrent symptomatic hemorrhage and associated functional impairment. World Neurosurg. 2016;91:73-80. doi:10.1016/j.wneu.2016.03.080

172. Tian KB, Zheng JJ, Ma JP, et al. Clinical course of untreated thalamic cavernous malformations: hemorrhage risk and neurological outcomes. J Neurosurg. 2017;127(3):480-491. doi:10.3171/ 2016.8.JNS16934

173. Aiba T, Tanaka R, Koike T, Kameyama S, Takeda N, Komata T. Natural history of intracranial cavernous malformations. $J$ Neurosurg. 1995;83(1):56-59. doi:10.3171/jns.1995.83.1.0056

174. Moriarity JL, Wetzel M, Clatterbuck RE, et al. The natural history of cavernous malformations: a prospective study of 68 patients. Neurosurgery. 1999;44(6):1166-1171; discussion 1172-1163.

175. Porter RW, Detwiler PW, Spetzler RF, et al. Cavernous malformations of the brainstem: experience with 100 patients. J Neurosurg. 1999;90(1):50-58. doi:10.3171/jns.1999.90.1.0050

176. Kondziolka D, Lunsford LD, Kestle JR. The natural history of cerebral cavernous malformations. J Neurosurg. 1995;83(5):820824. doi:10.3171/jns.1995.83.5.0820
177. Mathiesen T, Edner G, Kihlstrom L. Deep and brainstem cavernomas: a consecutive 8-year series. J Neurosurg. 2003;99(1):31-37. doi:10.3171/jns.2003.99.1.0031

178. Al-Shahi Salman R, Hall JM, Horne MA, et al. Untreated clinical course of cerebral cavernous malformations: a prospective, population-based cohort study. Lancet Neurol. 2012;11(3):217-224. doi:10.1016/S1474-4422(12)70004-2

179. Gross BA, Du R. Cerebral cavernous malformations: natural history and clinical management. Expert Rev Neurother. 2015;15 (7):771-777.

180. Cordonnier C, Al-Shahi Salman R, Bhattacharya JJ, et al. Differences between intracranial vascular malformation types in the characteristics of their presenting haemorrhages: prospective, population-based study. J Neurol Neurosurg Psychiatry. 2008;79 (1):47-51. doi:10.1136/jnnp.2006.113753

181. Hasegawa T, McInerney J, Kondziolka D, Lee JY, Flickinger JC, Lunsford LD. Long-term results after stereotactic radiosurgery for patients with cavernous malformations. Neurosurgery. 2002;50 (6):1190-1197. discussion 1197-1198. doi:10.1097/00006123200206000-00003

182. Chang SD, Levy RP, Adler JR, Martin DP, Krakovitz PR, Steinberg GK.Stereotactic radiosurgery of angiographically occult vascular malformations: 14-year experience. Neurosurgery. 1998;43(2):213220. discussion 220-211.

183. Kida Y, Kobayashi T, Mori Y. Radiosurgery of angiographically occult vascular malformations. Neurosurg Clin N Am. 1999;10 (2):291-303. doi:10.1016/S1042-3680(18)30195-5

184. Karlsson B, Kihlström L, Lindquist C, Ericson K, Steiner L. Radiosurgery for cavernous malformations. J Neurosurg. 1998;88 (2):293-297. doi:10.3171/jns.1998.88.2.0293

185. Kida Y, Hasegawa T, Iwai Y, et al. Radiosurgery for symptomatic cavernous malformations: a multi-institutional retrospective study in Japan. Surg Neurol Int. 2015;6(Suppl 5):S249-257. doi:10.4103/ 2152-7806.157071

186. Park K, Kim JW, Chung HT, Paek SH, Kim DG. Long-term outcome of Gamma Knife radiosurgery for symptomatic brainstem cavernous malformation. World Neurosurg. 2018;116:e1054e1059. doi:10.1016/j.wneu.2018.05.164

187. Liu HB, Wang Y, Yang S, Gong FL, Xu YY, Wang W. Gamma knife radiosurgery for brainstem cavernous malformations. Clin Neurol Neurosurg. 2016;151:55-60. doi:10.1016/j.clineuro.2016.09.018

188. Lee SH, Choi HJ, Shin HS, Choi SK, Oh IH, Lim YJ. Gamma Knife radiosurgery for brainstem cavernous malformations: should a patient wait for the rebleed? Acta Neurochir (Wien). 2014;156 (10):1937-1946. doi:10.1007/s00701-014-2155-0

189. Lee CC, Pan DH, Chung WY, et al. Brainstem cavernous malformations: the role of Gamma Knife surgery. J Neurosurg. 2012;117 (Suppl):164-169. doi:10.3171/2012.8.GKS121066

190. Lunsford LD, Khan AA, Niranjan A, Kano H, Flickinger JC, Kondziolka D. Stereotactic radiosurgery for symptomatic solitary cerebral cavernous malformations considered high risk for resection. $J$ Neurosurg. 2010;113(1):23-29. doi:10.3171/2010.1.JNS081626

191. Nagy G, Razak A, Rowe JG, et al. Stereotactic radiosurgery for deep-seated cavernous malformations: a move toward more active, early intervention. Clinical article. J Neurosurg. 2010;113(4):691699. doi:10.3171/2010.3.JNS091156

192. Kida Y. Radiosurgery for cavernous malformations in basal ganglia, thalamus and brainstem. Prog Neurol Surg. 2009;22:31-37.

193. Monaco EA, Khan AA, Niranjan A, et al. Stereotactic radiosurgery for the treatment of symptomatic brainstem cavernous malformations. Neurosurg Focus. 2010;29(3):E11. doi:10.3171/2010.7. FOCUS10151

194. Jacobs R, Kano H, Gross BA, Niranjan A, Monaco EA 3rd, Lunsford LD. Defining long-term clinical outcomes and risks of stereotactic radiosurgery for brainstem cavernous malformations. World Neurosurg. 2018. 
195. Sheen JJ, Lee DH, Lee DH, Song Y, Kwon DH. Long-term outcome of gamma knife radiosurgery for brain cavernoma: factors associated with subsequent De Novo Cavernoma formation. World Neurosurg. 2018;120:e17-e23. doi:10.1016/j.wneu.2018.07.046

196. Tu J, Stoodley MA, Morgan MK, Storer KP, Smee R. Different responses of cavernous malformations and arteriovenous malformations to radiosurgery. $J$ Clin Neurosci. 2009;16(7):945-949. doi:10.1016/j.jocn.2008.09.017
197. Nyary I, Major O, Hanzely Z, Szeifert GT. Pathological considerations to irradiation of cavernous malformations. Prog Neurol Surg. 2007;20:231-234. doi:10.1159/000100122

198. Shin SS, Murdoch G, Hamilton RL, et al. Pathological response of cavernous malformations following radiosurgery. J Neurosurg. 2015;123(4):938-944. doi:10.3171/2014.10.JNS14499

\section{Publish your work in this journal}

Therapeutics and Clinical Risk Management is an international, peerreviewed journal of clinical therapeutics and risk management, focusing on concise rapid reporting of clinical studies in all therapeutic areas, outcomes, safety, and programs for the effective, safe, and sustained use of medicines. This journal is indexed on PubMed Central, CAS,
EMBase, Scopus and the Elsevier Bibliographic databases. The manuscript management system is completely online and includes a very quick and fair peer-review system, which is all easy to use. Visit http://www.dovepress.com/testimonials.php to read real quotes from published authors. 